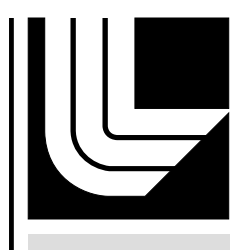

LAWRENCE LIVERMORE N A TIO NAL LABORATORY
Bazaar Diplomacy: Examining Iran's Nuclear Bargaining Tactics

Y. Lin

October 23, 2012 
This document was prepared as an account of work sponsored by an agency of the United States government. Neither the United States government nor Lawrence Livermore National Security, LLC, nor any of their employees makes any warranty, expressed or implied, or assumes any legal liability or responsibility for the accuracy, completeness, or usefulness of any information, apparatus, product, or process disclosed, or represents that its use would not infringe privately owned rights. Reference herein to any specific commercial product, process, or service by trade name, trademark, manufacturer, or otherwise does not necessarily constitute or imply its endorsement, recommendation, or favoring by the United States government or Lawrence Livermore National Security, LLC. The views and opinions of authors expressed herein do not necessarily state or reflect those of the United States government or Lawrence Livermore National Security, LLC, and shall not be used for advertising or product endorsement purposes.

This work performed under the auspices of the U.S. Department of Energy by Lawrence Livermore National Laboratory under Contract DE-AC52-07NA27344. 


\section{BAZAAR DIPLOMACY: \\ Examining Iran's Nuclear Bargaining Tactics}

Yang Bonny Lin

August 2012 
This research was conducted as part of the LLNL-MIIS Next General Safeguards Initiative's Safeguards Policy Internship. I would like to thank to my fantastic mentors (George Anzelon, Chris Carson, Jon Essner, Roger Miller, Justin Reed, and Celia Reynolds) and friends and colleagues (Jennifer Dahnke, Karen Hogue, Gisele Irola, Jon Pearl, Lovely Umayam, and Tristan Volpe) at Lawrence Livermore National Laboratory. I also owe special thanks to Siegfried Hecker, Neil Joeck, Mark Schanfein, Jessica Varnum, and Fred Wehling.

This document was prepared as an account of work sponsored by an agency of the United States government. Neither the United States government nor Lawrence Livermore National Security, LLC, nor any of their employees makes any warranty, expressed or implied, or assumes any legal liability or responsibility for the accuracy, completeness, or usefulness of any information, apparatus, product, or process disclosed, or represents that its use would not infringe privately owned rights. Reference herein to any specific commercial product, process, or service by trade name, trademark, manufacturer, or otherwise does not necessarily constitute or imply its endorsement, recommendation, or favoring by the United States government or Lawrence Livermore National Security, LLC. The views and opinions of authors expressed herein do not necessarily state or reflect those of the United States government or Lawrence Livermore National Security, LLC, and shall not be used for advertising or product endorsement purposes.

This work performed under the auspices of the U.S. Department of Energy by Lawrence Livermore National Laboratory under Contract DE-AC52-07NA27344. 


\section{Executive Summary}

Since undeclared elements of Iran's nuclear program were revealed in 2002, Tehran has engaged in a decade of efforts to justify and advance its nuclear program. Unlike North Korea's withdrawal from the Nuclear Nonproliferation Treaty (NPT), Iran has maximized advantage and minimized backlash by maneuvering near the borders of the NPT system. Iran has embraced a three-pronged approach to bargain with the international community: (1) divide international opposition, (2) delay international monitoring, negotiations, and sanctions, (3) and defy international monitoring, commitments, and pressure.

Iran's nuclear bargaining can be divided into several time periods, and Iran used divide, delay, and defy tactics in each period. During the first phase from 2003 to 2005, Iranian reformist leader Mohammad Khatami was more willing to negotiate with the international community, but his ability to negotiate was constrained domestically and particularly during his last year of leadership. Tehran mainly negotiated with the France, Germany, and the United Kingdom - the European 3 (EU-3) - to drive a wedge between European and U.S. pressures on Iran and to delay outside monitoring and prevent international sanctions.

It is in this early period that Iran developed its range of divide, delay, and defy tactics. For divide, Iran negotiated with the EU-3 because Europe had a close and influential relationship with the United States, whereas other international actors such as Russia and China were powerful but could not form an united bloc against the U.S. Iran began to delay international monitoring of its nuclear program by creating hurdles for international inspectors, stalling requests for information, and not volunteering information but providing updates only when Iranian nuclear developments were exposed by other parties. Iranian diplomats also delayed negotiations and sanctions by framing talks, negotiating and responding slowly to offers, providing false hopes and the appearance of concessions before key international events and resolutions, and adopting temporary and shifting negotiating positions. To defy, Iran modified and razed nuclear sites to prevent detection, used legalistic and minimal interpretations to subvert commitments, argued for an international right to enrich uranium, and proclaimed a fatwa against nuclear weapons.

After President Mahmoud Ahmadinejad came to power in 2005, Iran took a tougher stance internationally. Ahmadinejad and his cabinet did not provide major concessions to facilitate international negotiations, were less willing to seriously consider proposals to curb Iran's nuclear program, and linked Iran's nuclear program to sovereignty and national pride. Realizing that Europe was less optimistic about negotiations, Ahmadinejad leveraged Russia and China to Iran's advantage. Both countries helped delay and dilute United Nations Security Council resolutions against Iran.

Ahmadinejad employed more tactics to defy international monitoring and pressure. These tactics involved demonstrating Iran's nuclear progress even as Tehran engaged in negotiations over its program. Iran also increased the cost of failed negotiations by sustaining and escalating regional and global tensions to coincide with international events and resolutions that criticized or condemned Iran's nuclear program.

The third and present phase of Iranian nuclear bargaining began during Ahmadinejad's second term as president (2009-2012). During this period, Ahmadinejad's power significant weakened and domestic turf wars made Iranian nuclear negotiations unpredictable and at times contradictory. Due to the domestic situation and the exhausting of successful divide and delay tactics, Iran began using more defy tactics. Iran, for example, considered enriching uranium to a higher percentage for naval reactors, warned of closing the Straits of Hormuz, and engaged in terrorist acts against the West and its allies.

Currently, Iran's range of bargaining options has narrowed, with many divide and delay tactics less useful since the international community has become more aware of Iranian efforts to stall and buy time. While Iran leaders have employed more acts of defiance, Iran's ability to sustain its defy tactics are waning and it is still possible to prevent greater confrontation between Iran and the West. 


\section{Introduction}

Since undeclared elements of Iran's nuclear program were revealed in 2002, Tehran has engaged in a decade of bargaining to justify and advance its nuclear program. During these ten years, Iran enhanced its sensitive nuclear capabilities despite international opposition. The International Atomic Energy Agency (IAEA) has come to monitor 16 declared Iranian nuclear facilities, including three uranium enrichment facilities, three uranium fabrication and conversion facilities, and six nuclear reactors. ${ }^{1}$ The May 2012 IAEA Board of Governors report indicated that Iran has installed more than 11,000 centrifuges ${ }^{2}$ and has produced "6197 $\mathrm{kg}$ of $\mathrm{UF}_{6}$ enriched up to $5 \% \mathrm{U}-235$ and $145.6 \mathrm{~kg}$ of $\mathrm{UF}_{6}$ enriched up to $20 \% \mathrm{U}-235$." 3

This research examines Iran's nuclear bargaining with international community from 2003 onwards to understand how Iran has withstood international pressure to proceed with its nuclear program. Unlike North Korea's withdrawal from the Nuclear Nonproliferation Treaty (NPT), Iran has maximized advantage and minimized backlash by maneuvering within and near the borders of the NPT system. To do so, Iran has embraced a three-pronged approach that divides international opposition and delays and defies international monitoring and sanctions. While it is unclear what long-term strategic objectives Iran wishes to achieve with its nuclear capabilities, Tehran has successfully bargained to gain time for its nuclear program.

This research first explores Iranian bargaining behavior before dissecting the divide, delay, and defy tactics that Iran has and currently uses to complicate international efforts to check its nuclear program. The paper concludes by examining how various factors may be changing Iran's ability to bargain with the international community.

\section{Overview of Iranian Nuclear Negotiations, 2003-2012}

From 2003 onwards, Iran's nuclear negotiations can be divided into three key phases: 2003-2005 under reformist President Mohammad Khatami, 2005-2009 under hardline President Mahmoud Ahmadinejad's first term, and 2009-2012 under a significantly weakened Ahmadinejad.

\section{Iran under Mohammad Khatami, 2003-2005}

Iranian leaders were more willing to negotiate with the international community before 2005. President Mohammad Khatami (1997-2005) sought to reform Iran by easing its international isolation. ${ }^{4}$ Khatami was aware of the potentially dangerous implications of continuing undeclared nuclear work ${ }^{5}$ and was willing to cooperate with international efforts to monitor its nuclear program. In February 2003, Iran agreed to the modified text of Code 3.1 of Subsidiary Arrangement General Part, which requires Iran to provide the IAEA preliminary design information for new facilities "as soon as the decision to construct or to authorize construction has been taken." After the U.S. invasion of Iraq, Iran proposed a grand bargain with the United States. Iran offered to cooperate on a number of issues - including signing the Additional Protocol and providing "full transparency for security that there are no Iranian endeavors to develop or possess WMDs" - in exchange for a long-term understanding with the U.S. that ended sanctions and recognized Iranian rights and security interests. ${ }^{7}$ When U.S. President George W. Bush rejected the Iranian offer, Khatami and his cabinet concluded a voluntary agreement with France, Germany, and the United Kingdom - the European 3 (EU-3) - to suspend its uranium enrichment in October 2003. The Iranian leaders believed that the agreement would be a short-term measure to demonstrate that Iran's nuclear program was peaceful. ${ }^{8}$

Khatami's ability to negotiate with the U.S., however, was constrained by politics at home. Revelation of and scrutiny over Iran's undeclared nuclear work in 2002 made the nuclear issue a key domestic concern. Khatami and his administration emphasized that civilian nuclear energy would help Iran reduce its 
reliance on oil and gas and contribute to the country's modernization. They did not claim that the nuclear program would augment Iran's defense, arguing instead that pursuing nuclear weapons would undermine Iran's security. ${ }^{9}$ The domestic discussion soon acquired nationalist tones and pressure emerged for the Khatami government to under no circumstances surrender Iran's "sovereign national right" to enriching uranium. $^{10}$

The hardliners, however, were gaining influence in Iran and encouraged Tehran to adopt tougher negotiating positions. The February 2004 Iranian parliament (Majles) election brought to power 91 members of the Iranian Revolutionary Guard Corps (IRGC), "with a further 34 former IRGC careerists [holding] senior-level political posts in the government." "11 Throughout 2004, Iran's voluntary implementation of the Additional Protocol was not sufficient to assure the international community that its nuclear program was only for peaceful purposes or to put to rest previously revealed Iranian failures to report and disclose nuclear-related efforts. ${ }^{12}$ Under the influence of the new parliament and frustrated that Iran's efforts to build confidence had instead raised more concern and demands, Iranian leaders hardened their positions. In early 2005 , Khatami, who typically denied Iran had any interest in nuclear weapons, hinted that diplomatic pressure may force Iran to withdraw from the NPT. Similarly, then Defense Minister Ali Shamkhani discussed nuclear counterattack and preemption despite previously renouncing the nuclear option. ${ }^{13}$ In late April 2005, Iranian Supreme Leader Ayatollah Ali Khamenei gave an order to the Khatami regime to begin operation of the Isfahan Uranium Conversion Facility, a plant that converts yellowcake into uranium hexafluoride $\left(\mathrm{UF}_{6}\right){ }^{14}$

\section{Iran under Mahmoud Ahmadinejad, 2005-2009}

Whereas Europe stalled negotiations in early 2005 in hopes that a more moderate candidate - Hashemi Rafsanjani - would win the 2005 Iranian presidential elections, Mahmoud Ahmadinejad came to power. By this time, Iranian leaders had become doubtful that negotiations with the EU-3 would produce quick and favorable results. Before Ahmadinejad assumed power, Khamenei had convened Iranian leaders across the different power centers - with then reformist President Khatami, pragmatist Expediency Council Chairman Rafsanjani, President-elect and hardliner Ahmadinejad, and reformist and former prime minister Mir Hossein Moussavi - to present a unified, internal consensus that if Europe did not provide Iran with an acceptable offer, Iran would restart work at Isfahan. ${ }^{15}$ When negotiations failed to achieve a breakthrough, Iran resumed uranium conversion activities in August. From late 2005 onwards, Iran combined diplomacy with a calibrated resumption and initiation of nuclear activities.

The Ahmadinejad administration shaped nuclear negotiations in several ways. First, the new administration relied more on the influence of Russia and China to counter U.S. pressures. ${ }^{16}$ Second, Ahmadinejad's regime did not provide major concessions to facilitate negotiations. In May 2006, for example, the U.S. offered to join nuclear talks if Iran first suspended uranium enrichment. Iran refused. ${ }^{17}$ Instead, as time passed, Tehran reversed previous agreements. Iran stopped voluntarily implementing the Additional Protocol in February 2006 and renounced the modified Code 3.1 in March 2007.

Third, as Iran's program developed, there were fewer proposals that Ahmadinejad and his cabinet members offered and seriously considered. Iran negotiated but ultimately rejected a 2005 Russian offer to share ownership of a uranium enrichment plant located in Russia, a 2005 comprehensive offer by the EU3 in, a 2006 tentative deal between Iranian nuclear negotiator Ali Larijani and UK Foreign Minister Jack Straw and European Union High Representative Javier Solana, and two proposals by the five permanent members of the U.N. Security Council and Germany (the P5+1). Whereas the Larijani deal may have died due to domestic infighting, Iran was hardly serious in its negotiations on the rest - Iran either rejected the proposals or responded with vague counterproposals that did not sufficiently detail the steps Iran would take to alleviate international concern over its nuclear program. ${ }^{18}$ While Iran agreed to the 2007 IranIAEA Modalities Plan, Iran failed to address the possible military dimensions of its nuclear work. ${ }^{19}$ 
Ahmadinejad's 2007 proposal for co-owned enrichment facilities located on Iranian soil was further not accepted by the West. ${ }^{20}$ During this period, Iran thus mainly sought to buy time for its program.

Fourth, Iran has more openly defied western efforts to curb its nuclear program. As the west ratcheted up pressure against Iran through UNSC resolutions, sanctions, and threat of force, Iran signaled its resolve to continue nuclear development. Iran's decision to suspend its implementation of Code 3.1 of the Subsidiary Arrangements on March 29, 2007 occurred after increasing displays of force and military threats from the U.S. earlier in the year. ${ }^{21,22}$ On July 23, 2008, Ahmadinejad further rejected international demands that Iran cease uranium enrichment and called on the UNSC to accept Iran's right to enrich. ${ }^{23}$

Iran may have further authorized - or did not prohibit - using force to bolster its nuclear program. Iran may have given a green light to Hezbollah to launch the Lebanon War on July 12, 2006 - the deadline for Iran to respond to a $\mathrm{P} 5+1$ offer - to divert attention away from Iran's nuclear program and to gain a negotiating leverage. ${ }^{24}$ Iran has also armed and trained Shiite militias in Iraq "to bog down the United States militarily and to deter it from military or diplomatic action against Iran's nuclear program." 25

Finally, Ahmadinejad politicized nuclear issues, making Iran's nuclear negotiations with the West difficult by linking Iran's nuclear program to sovereignty and pride. The president preached about Iran's nuclear rights, created stamps for Natanz, and declared a 'nuclear awareness day'. ${ }^{26}$ Nuclear issues and confrontation with the West also served as a smokescreen, keeping critics from effectively attacking Ahmadinejad's inability to deliver on promised economic reforms. ${ }^{27}$

\section{Iran under a weakened Mahmoud Ahmadinejad, 2009-2012}

Ahmadinejad's power eroded during his second term. The June 2009 Iranian presidential elections were charged with fraud, with reformist candidate Moussavi declaring himself the legitimate winner instead of Ahmadinejad. ${ }^{28}$ The election dispute led to massive street protests across Iran. Deadly clashes between the protesters and security forces widened the split among Iranian elites on how to deal with the domestic turmoil. Though many leading reformists were politically imprisoned or silenced, there was significant sympathy with the protestors among Iranian elites. While Khamenei supported Ahmadinejad, the Supreme Leader was also aware that the president's radical policies and failure to improve Iran's economy were becoming liabilities. As Khamenei reigned in Ahmadinejad's influence, the Iranian president more openly challenged the Supreme Leader's authority without much success. ${ }^{29}$

Domestic turf wars have made Tehran's nuclear negotiations unpredictable. The different Iranian power centers have changed positions to upstage each other and undercut nuclear negotiations. Though the reformists and pragmatists typically favor negotiating, they blocked Ahmadinejad's nuclear fuel swap deal in October 2009. ${ }^{30}$ Iranian leaders have further contradicted each other in public, making it difficult to discern who represents Iranian interests. ${ }^{31}$ Since late 2011, Ahmadinejad has adopted positions that undermine efforts by the Supreme Leader to negotiate with the West - Ahmadinejad both advocated dialogue and yet criticized the 'softer' approach taken by Khamenei's negotiators. ${ }^{32}$

While the international community has applied more sanctions and threats to Iran, it is unclear how these coercive measures are affecting the power centers in Iran and Iran's nuclear behavior. On one hand, the reformists campaigned on Ahmadinejad's "mismanagement of the economy" - not unrelated to the crippling effect of sanctions - in the June 2009 presidential elections. ${ }^{33}$ On the other hand, Moussavi has argued that sanctions are hurting the people and their base of support and generate more support for Ahmadinejad. ${ }^{34}$ Mirroring the dual-track approach adopted by the U.S., Tehran has embraced more negotiations while demonstrating greater resistance. In the first eight months of 2012, for example, Iran has participated in three P5+1 plenary negotiation sessions, the same number of sessions held from 2009 to 2011. This same period, Iran engaged in several military tests and exercises and threatened (and partially retracted) to block the Straits of Hormuz. ${ }^{35}$ 
Various developments, however, suggest that Iran may be at a critical juncture of 'drinking the poison' and accepting a negotiated solution or preparing for a potential military showdown. On one hand, Iran continues to make gradual progress in its uranium enrichment program. Iranian elites have debated enriching uranium to higher levels for nuclear submarine fuel, which would provide Iran with what it deems to be a plausible rationale for breaking the $20 \%$ barrier while establishing a capability to produce potentially weapons-usable material. ${ }^{36}$ Reza Taqavi, an aide to Khamenei, further warned that "Iran is now capable of enriching uranium at a 20-percent level, but if they (world powers) continue their pressure, we will increase enrichment levels to 56 percent." ${ }^{37,38}$ Iranian military leaders are aware that Iran has "reached a very sensitive and fateful stage" in which the West is waging a "soft war" on Iran and military action may be pending. ${ }^{39}$

On the other hand, Iranian leaders appear to be signaling an opening towards negotiations. Supreme Leader Khamenei has criticized the 'extremism' that led to the British embassy being overrun in November $2011^{40}$ and lectured to university students about "the need for lenience and broadmindedness in encountering people with viewpoints that vary with ours in various matters, including [the] political field." ${ }^{" 41}$ Similarly, Rafsanjani, a pragmatist and former president, has become more visible after being sidelined early in Ahmadinejad's second term. He has welcomed criticisms from the media on the hardships Iran faces ${ }^{42}$ and called for a foreign policy of détente. ${ }^{43}$ Other Iranian officials have suggested that Iran might be interested in downgrading its enrichment activity in exchange for ending sanctions. ${ }^{44}$ Even if Iran is more willing to accept a negotiated solution, Iran may still wish to keep a significant latent nuclear capability as a hedge against possible hostile military action (the Western attack on Libya may have alerted Iranian leaders that giving up nuclear capabilities may provide the West with a freer hand to launch an attack on the country in the future). ${ }^{45}$

\section{III: Iranian Nuclear Bargaining Tactics: Divide, Delay, and Defy}

At this critical juncture, it is important to understand the tactics Iran has utilized to advance its nuclear program in the past ten years. Iran's tactics can be grouped into three main categories. Iran works to: (1) divide international opposition, (2) delay international monitoring, negotiations, and sanctions, (3) and defy international monitoring, commitments, and pressure. This section explores each category in detail.

\section{Dividing international opposition}

Tehran repeatedly seeks to divide the international community and empowers parties amenable to its agenda. Over the years, Iran has relied on Europe, Russia, China, and other powerful international actors to lobby in Iran's favor against sanctions and other punitive measures.

Negotiating with Europe: The Khatami administration, for example, worked to "deepen the transatlantic divide." ${ }^{46}$ According to Seyed Hossein Mousavian, nuclear negotiator at the time, Iran dealt with the European Union in 2003 to use Europe to check the U.S. push for punitive measures. In 2002, Europe had a positive view on Iran. Iranian-European relations were flourishing on multiple levels and negotiations were underway for Trade Cooperation and Political Dialogue Agreements. ${ }^{47}$ Europe could influence the U.S. whereas other countries had less bargaining power: the Non-Aligned Movement, Russia, and China were not unified and the U.S. could "creat[e] rifts among those countries." 48 The October 2003 Tehran Agreement negotiated with the EU-3 thus "extricat[ed] Iran to a degree from the demands of the [IAEA] September 2003 resolution." 49 The previous consensus that Iran must suspend nuclear activities was downgraded to Iran voluntarily and temporarily suspending such activities. In return, the EU-3 opposed referring Iran to the UNSC and objected to using the word "noncompliance" in the next IAEA resolution. ${ }^{50}$ Similarly, Iran's November 2004 Paris Agreement with the EU-3 encouraged the IAEA to adopt a milder resolution the same month. ${ }^{51}$ While Iran violated successive agreements, the talks gave an 
appearance of Iranian cooperation that lessened the U.S. case for military action. The talks also motivated the EU to not refer Iran to the UNSC until January 2006, when Iran began uranium enrichment. ${ }^{52}$

Leveraging Russia and China: From late 2005 onwards, the Ahmadinejad administration shifted focused to Russia and China. Iran's turn to these other actors was caused by Europe's growing pessimistic view of dealing with Tehran. Despite negotiations, the IAEA found Iran to be in non-compliance with its NPT obligations in September 2005, paving the way for Iran's case to be referred to the U.N. Security Council. Iran thus needed stronger allies to block UNSC resolutions that might give the illusion of international opposition to Iran's nuclear program and might give the U.S. more reason to pressure Iran. Russia and China were permanent members of the UNSC that did not share the portfolio of U.S. strategic interests.

Russia and China have repeatedly delayed and diluted the four UNSC resolutions on Iran from 2006 to $2010 .^{53}$ In November 2005, the IAEA delayed referring Iran to the UNSC to give chance to a Russian proposal that would allow Iran to enrich uranium on Russian soil. ${ }^{54}$ For Resolution 1696 passed July 2006, both Russia and China blocked harsher language and urged for patience. ${ }^{55}$ For Resolution 1737 of December 2006, Russia narrowed sanction provisions, allowing more leeway to export nuclear-related technology and materials to Iran. ${ }^{56}$ China prevented Resolution 1747 of March 2007 from placing sanctions on governmental loans for firms operating in Iran ${ }^{57}$ China also delayed U.S. efforts for more sanctions in December 2009 by not agreeing to discuss sanctions until March 2010 and not reaching agreement on Resolution 1929 until nine weeks later. ${ }^{58}$

From mid-2010 onwards, China and Russia have opposed more UN sanctions, leaving the United States and its partners resorting to unilateral or other multilateral sanctioning mechanisms. In February 2011, Moscow opposed sanctions and offered in July a "step-by-step" initiative to gradually reduce sanctions in return for Iranian cooperation with the IAEA. ${ }^{59}$ Moscow further criticized the November 2011 IAEA report on Iran as "juggling with information in order to create an impression that the Iranian nuclear program allegedly has a military component" and worked to prevent another P5+1 sanctions draft. ${ }^{60}$ Russia and China's actions have bought Iran significant time for its program - one analyst assesses that "Beijing's delaying tactics [by itself] probably gained several years of time for Tehran."

Employing other actors: Along with the above, Iran has also brought in other key international actors to support Iran's program. Iran preferred to work with Mohamed ElBaradei, head of the IAEA from 1997 to 2009. ElBaradei downplayed potentially incriminating evidence from Iran. Iran may have agreed to suspend nuclear activities in 2003 when ElBaradei provided Iran with an interpretation of suspension narrower than envisioned by the European negotiators. ${ }^{62}$ While the NCRI revealed the existence of Lavizan-Shian in May 2003, ElBaradei did not act on the information until over a year later when ISIS and international media reported suspicious razing and sanitization of the site. ${ }^{63}$ In spring 2006, ElBaradei removed chief IAEA Iran inspector Christopher Charlier in response to complaints from Iran. ${ }^{64}$ ElBaradei further criticized using UNSC sanctions to limit Iran's program as "a misuse of the council's authority under Chapter VII of the UN Charter.",65

Similarly, Iran negotiated a fuel swap agreement with Brazil and Turkey in 2010 to dilute global pressure. At that time, Brazil and Turkey were on the IAEA Board of Governors and members of the UNSC. While Washington rejected the negotiated deal, the process caused Brazil and Turkey to vote against the June 2010 UNSC Resolution 1929. This was a diplomatic victory for Iran since the previous three rounds of UN sanctions against Iran had no negative votes, only abstentions. ${ }^{66}$

Overall, Iran has continuously sought to divide the international community. While international actors were initially willing to give Iran the benefit of the doubt, Iran is beginning to exhaust the patience of even its strongest backers. ${ }^{67}$ Though Russia and China may be wary of more UNSC sanctions on Iran, Tehran is unlikely to lure in other key international actors to its defense. 


\section{Delaying international monitoring, negotiations, and sanctions}

Iran employs a number of measures to delay international monitoring, prolong negotiations, and defer sanctions. While some cases of delays may be less intentional and the outcome of domestic power struggles, Iran has been able to gain time with such measures. This section points out two methods Iran has employed to delay each type of international action.

Delaying investigation: Iran delays international investigation of suspect nuclear sites in two main ways. First, Iran does not volunteer any information to the IAEA and provides the IAEA with updated and shifting explanations for nuclear developments after detection. From 2002 to 2003, the opposition group National Council of Resistance of Iran exposed Iran's Natanz, Arak, Kalaye Electric, and Lashkar Ab'ad sites, forcing Iran to declare its nuclear work. ${ }^{68}$ Similarly, Iran announced its Fordow site in September 2009 when Western countries were about to disclose it. Iran preferred to inform the IAEA of detected but not yet exposed facilities "to spin it as evidence of Iranian transparency." ${ }^{69,70}$ Fordow, however, had been under construction from at least 2007, with some buildings present already in $2002 .^{71}$

Second, Iran creates procedural difficulties, stalls access to suspect sites, and responds slowly to requests for information. Iran has particularly made granting the IAEA access to its facilities difficult, as shown in Table 1 below. The IAEA, for example, asked to visit Natanz and Arak in 2002 but did not get in until 2003 . $^{72}$ Of the first five Iranian nuclear sites listed on the table, the IAEA did not conduct environmental sampling until 5 to 13 months (with an average of near 8 months) after the sites were publicly revealed by the NCRI. Fordow was under construction for well over two years before the IAEA even requested a visit and Iran still does not have full access to Parchin.

Table 1: Delay in IAEA access to key Iranian nuclear sites

\begin{tabular}{|l|l|l|}
\hline \multicolumn{1}{|c|}{ Sites } & \multicolumn{1}{|c|}{ IAEA requested access } & \multicolumn{1}{c|}{ IAEA granted access } \\
\hline $\begin{array}{l}\text { Natanz \& } \\
\text { Arak }\end{array}$ & $\begin{array}{l}\text { Sep 2002 (NCRI revealed site } \\
\text { Aug 2002) }\end{array}$ & $\begin{array}{l}\text { Visit (Feb 2003 after postponed in Oct 2002 \& } \\
\text { Dec 2002), environmental sampling (Mar 2003) }\end{array}$ \\
\hline $\begin{array}{l}\text { Kalaye } \\
\text { Electric }\end{array}$ & $\begin{array}{l}\text { Feb 2003 (NCRI revealed site } \\
\text { Feb 2003) }\end{array}$ & $\begin{array}{l}\text { Visits (Mar 2003; May 2003), environmental } \\
\text { sampling (Aug 2003) }\end{array}$ \\
\hline $\begin{array}{l}\text { Lashkar } \\
\text { Ab'ad }\end{array}$ & $\begin{array}{l}\text { May 2003 (NCRI revealed site } \\
\text { May 2003) }\end{array}$ & $\begin{array}{l}\text { Visit (Aug 2003), environmental sampling (Oct } \\
\text { 2003) }\end{array}$ \\
\hline Parchin & Jun 2004; Jan 2012 & $\begin{array}{l}\text { Visit and sampling limited to five buildings in one } \\
\text { of four sectors (Jan 2005); no access for 2012 } \\
\text { requests }\end{array}$ \\
\hline Fordow & $\begin{array}{l}\text { Sep 2009 (construction started by } \\
\text { Visit and environmental sampling (Oct 2009) }\end{array}$ \\
\hline
\end{tabular}

Even when the Agency has been granted access, Iran often has created additional hurdles. When international inspectors requested to visit Lashkar Ab'ad, Iranian officials first took inspectors to another location, pretending that it was the site the inspectors wished to examine. ${ }^{73}$ From 2003 to 2010, for instance, Iran has asked the IAEA to withdraw the designation of forty-two inspectors. ${ }^{74}$ IAEA Director Yukiya Amano lamented: "Iran's repeated objection to the designation of inspectors with experience in Iran's nuclear fuel cycle and facilities hampers the inspection process. ${ }^{, 75}$

Prolonging negotiations: Iran also prolongs negotiations. First, Iran frames the talks by setting preconditions and agenda items for talks and determining the time and venue of negotiations to limit unfavorable international actions during the duration of negotiations. ${ }^{76}$ In the 2007 Iran-IAEA Modalities Plan, for example, Iran agreed to address the alleged studies (now termed possible military dimensions of 
its nuclear program) only after a host of other issues have been resolved or 'closed.' This agreement may have motivated the IAEA to quickly resolve issues it had with Iran in order to deal with the more important alleged studies. ${ }^{77}$ In 2012, Iran requested technical meetings and deputy-level meetings before its main nuclear negotiator Saeed Jalili was willing to talk to his counterpart. ${ }^{78}$

Second, Iran responds slowly - often after set deadlines - to offers and proposals. Iran, for example, asked to respond to June 2006 EU-3 proposal by August 22 instead of the previously set July 12 deadline. On July 31, 2006, the UNSC voted for Resolution 1696 that gave Iran until August 31, 2006. On August 22, Iran submitted a 21 page formal response that fell short of what Resolution 1696 required. ${ }^{79}$ Similarly, President Obama and other P5+1 leaders reached out to Iran with a package of proposals in April 2009. Iran did not respond until September and negotiations did not take place until October. When Iran indicated interest in the deal, the P5+1 gave Iran a December 31, 2009 deadline to reach agreement. Iran, however, took an additional three weeks after the December deadline to officially reject the deal: taking a total of 111 days after negotiations took place to respond. ${ }^{80}$

Deferring sanctions: Iran further defers international sanctions by engaging in negotiations preceding key international events and deadlines, such as before IAEA or UNSC meetings. In these negotiations, Iran may provide smaller concessions to indicate the country's willingness to cooperate to derail criticism and pressure for sanctions. In January 2006, for example, Iran provided IAEA with access to sample certain equipment that had been removed from the Lavizan-Shian military site, in the hopes that this increment of cooperation might "derail an American and European initiative to immediately send Iran's nuclear case for judgment by the United Nations Security Council." ${ }^{81}$ Similarly on October 30, 2011 before the IAEA's November 8 report on Iran, Iran invited IAEA Safeguards Department head Herman Nackaerts to Tehran - after the IAEA report was published - for talks "aiming at a resolution of matters." The invitation tried to signal transparency and may have given Nackaerts "a chance to ask for a renewed trip to Parchin that included a visit to the suspected building." $"$ "When the November IAEA report noted its concern with the possibly military dimensions of Iran's program, Iran canceled the invitation.

Along with smaller concessions, Iran has used temporary and shifting negotiating positions to push off sanctions. In October 2005, for example, Russia proposed a joint Iranian-Russian venture to enrich uranium on Russian soil. "Iran vacillated for months, alternatively rejecting and agreeing to consider this proposal numerous times, never making its position entirely clear." ${ }^{, 3}$ While the international community grew tired and imposed sanctions on Iran in 2006, the IAEA (as mentioned above) delayed referring Iran to the UNSC in November 2005 to give the Russian proposal a chance. ${ }^{84}$ Similarly, Iran has indicated an on and off interest in fuel swap deals from 2009 onwards. In October 2009, Iran initially agreed to a fuel swap agreement with the P5+1, which may have influenced the IAEA report the next month that did not find Iran to be in official noncompliance. Iran was thus not referred to the UNSC for sanctions in November 2009 as it deliberated the Tehran Research Reactor proposal. ${ }^{85,86}$ Iran, however, rejected the P5+1 deal in early 2010 to embrace a similar but new agreement with Turkey and Brazil in May 2010 . While Iran may have hoped that negotiating with Turkey and Brazil would lessen the international pressure towards sanctions, the UNSC agreed to Resolution 1929 in June 2010.

While Iran's efforts to delay international monitoring may be intentional, it is important to note that some of the delays witnessed in Iran's nuclear negotiations and Iran's seemingly defiant shifting nuclear positions may be driven by the lack of agreement among power centers in Iran. In other words, domestic infighting in Tehran may contribute to deadlock, wavering, or contradictory stances. 


\section{Defying international monitoring, commitments, and pressure}

Iran also defies international monitoring, undermines international commitments, and resists global pressure. Iran has limited the IAEA's ability to detect its nuclear developments and violated international agreements. To counter international pressure, Iran demonstrates its determination to continue nuclear work and may have increased regional tensions to bargain with the international community.

Defying monitoring: First, Iran defies international monitoring by engaging in modification, cleanup, and demolition of sites to prevent the IAEA from resolving questions about possible hidden nuclear activities. The Agency found low-enriched uranium (LEU) and highly enriched uranium (HEU) particles at four locations in Iran in 2003 and Iran modified or concealed activities at these sites. In February 2003, following the NCRI's declaration that Iran engaged in undeclared uranium enrichment at Kalaye Electric Company, IAEA requested access. ${ }^{87}$ Iran provided IAEA with limited access in March 2003, full access in May 2003, and agreed to environmental swipes in August 2003. During the August visit, IAEA noted that "there had been considerable modification of the premises since their first visit in March 2003." 88 "The renovation," according to the IAEA, "which was carried out in connection with Iran's attempt to conceal the activities carried out there, has interfered with the Agency's ability to resolve issues associated with Iran's centrifuge enrichment programme." 89 At Pars Trash and Farayand Technique - two other locations where the IAEA found uranium particles - Iran sought to prevent future IAEA monitoring by changing the names and addresses of the companies after IAEA inspections. ${ }^{90}$

The two most glaring examples of Iran's attempts to prevent the IAEA from detecting suspicious nuclear behavior involve Iran's razing of Lavizan-Shian and Parchin, two military sites. In May 2003, the NCRI identified Lavizan-Shian as a suspected site of centrifuge and laser enrichment work. By late 2003 to early 2004, Iran razed the site and removed all the equipment, raising international concern. In June 2004, the IAEA inspected the site without discovering any nuclear activities. In January 2006, however, the Agency found "a small number of particles of natural and high enriched uranium" at equipment at a technical university "shown to the Agency in connection with its investigation into efforts made by the Physics Research Centre (PHRC) to acquire dual use material and equipment." ${ }^{, 1}$ Lavizan-Shian had housed the PHRC. ${ }^{92}$ Similarly the IAEA requested access to Parchin suspecting undeclared nuclear work in June 2004. The IAEA was allowed limited access on January 2005 after Iran cleaned up the site in late 2004. Iran only "permitted the IAEA to visit one of four sectors at the site and only five buildings in that area, but inspectors then saw no evidence of nuclear-related activities." ${ }^{93}$ In January 2012, the international community suspected that Iran may have conducted high-explosives work related to nuclear weapons design at a specific location at Parchin, and the Agency requested access to "one specific building." 94 As of Fall 2012, Iran has yet to provide the IAEA with access. Iran has, however, engaged in concealment at the site, with "two buildings demolished, excavation of earth including most of the surrounding vegetation and roads covered or removed, dismantlement of the security perimeter around the site, and evidence of water usage potentially for cleaning the insides of buildings." 95

Iran has also limited IAEA monitoring capabilities. In February 2006, Iran stopped voluntarily implementing the Additional Protocol, limiting IAEA access to Iranian nuclear facilities. Similarly in March 2007, Iran renounced the modified Code 3.1 of the Subsidiary Arrangements General Part to Iran's Safeguards Agreement, something the IAEA contends Iran has no right to do unilaterally. Since then, Iran has defended its stance to not supply the IAEA with early design information for nuclear facilities under construction. For example, Iran last provided the IAEA with design information for its IR-40 Reactor in in 2007. However, since then, "Iran has conducted significant additional design and construction work on the reactor, but has not provided further information. The lack of up-to-date information on the reactor is now having an adverse impact on the Agency's ability to effectively verify the design of the facility." 96 Similarly, Iran did not provide the IAEA with information about construction of its Fordow facility until 
September 2009 when the facility, which had been detected by Western intelligence, was about to be disclosed publicly. ${ }^{97}$

Undermining commitments: Iran has also undermined its international commitments by using minimal and legalistic interpretations to find loopholes and violate the spirit of agreements. Iran has also repeatedly renegotiated and rejected previous agreements. Iran's negotiations with the EU-3 from 2003 show several examples. In October 2003, Iran agreed to suspend uranium enrichment but interpreted it as "consist[ing] of only the suspension of the introduction of gas [UF6]" into the centrifuge enrichment cascade, preferring to use an alleged interpretation of suspension provided to Iran from then IAEA Director General Mohamed ElBaradei. ${ }^{98}$ Iran's use of the narrowest understanding of its obligations caused the EU-3 to renegotiate an agreement in February 2004, when Iran agreed to also "suspend the manufacture of parts and assembly of centrifuges." $" 99,100$

Soon after signing the February 2004 Brussels Agreement, Iran again undercut the agreement. Tehran engaged in "round-the-clock activity in centrifuge assembly just before the suspension began in April 2004." ${ }^{\prime 101}$ Europe had understood the Brussels Agreement to mean that Iran would suspend manufacturing and assembly of centrifuges immediately after the Brussels Agreement whereas "Tehran believed that it was committed to suspending the manufacturing and assembly of centrifuges before the June meeting of the IAEA Board of Governors." 102 When Iran finally agreed to suspend the manufacturing of centrifuges parts, Iran violated the spirit by announcing the entry into service of a uranium conversion facility at Esfahan on March 2004. ${ }^{103}$ The facility was intended to convert uranium ore into $\mathrm{UF}_{6}$, which can then be used as feed for uranium enrichment. When the IAEA objected to the facility, Iran informed the Agency that "the decision taken for voluntary and temporary suspension is based on clearly defined scope which does not include suspension of production of $\mathrm{UF}_{6}$." 104,105

Given the loopholes in the previous two agreements, the EU-3 negotiated a third November 2004 Paris Agreement with Iran where Iran agreed to suspend all enrichment-related activities. Iran, however, still violated the spirit of the agreement by trying to keep twenty centrifuges open to 'research and development' and using 'quality control checks' to test parts of machines used for enrichment despite agreeing to no enrichment. There were allegations that "the high number of parts the Iranians subjected to quality controls possibly indicated that they had more centrifuges built than commonly thought."106,107 Iran eventually terminated the agreement in August 2005 by reopening its Esfahan conversion facility. ${ }^{108}$

Resisting pressure: Finally, Iran has embraced a number of measures to resist international sanctions and pressure to relinquish its nuclear program. First, Iran has emphasized its right to enrich based on internationally agreed upon uses of nuclear energy. Iran continues to argue for enrichment for medical isotopes and enrichment beyond the $20 \%$ level for naval submarines. ${ }^{109}$ Tehran has also maintained that UNSC resolutions that demand Iran halt enrichment are illegal. ${ }^{110}$

Second, Iran has proclaimed the existence of a religious edict or fatwa that prohibits Iran from producing, stockpiling, or using nuclear weapons. However, the fatwa has never been written down and Iran has historically practiced the Shia doctrine of taqiyya, or spreading disinformation to defend its faith. ${ }^{111}$

Third, Iran demonstrates its determination to continue nuclear work to resist international pressure and appear strong in front of its domestic audience. Iranian leaders believe that Tehran should negotiate from a position of strength and showcasing Iran's resolve to continue nuclear work signals that Iran is not willing to give in easily to international pressure. Iranian leaders believe that as Tehran's nuclear capability increases, Iran will have a greater bargaining advantage in international negotiations in the future than now. ${ }^{112}$ Iran thus repeatedly highlights select nuclear progress when negotiating with the international community. In May 2010, for example, Iran announced it would continue enriching uranium to $20 \%$ just hours after signing the Brazil-Turkey-Iran nuclear swap agreement. 
Fourth, Iran also defies international pressure by increasing the costs of failed international negotiations. Iran has sustained or escalated regional tensions to pressure the West to agree to Iranian terms. Iran responded to all four UNSC resolutions that strengthened sanctions against Iran with threats and actions. On March 2, 2008, for example, one day before the passage of UNSC Resolution 1803, Ahmadinejad became the first Iranian president to visit Iraq since the Iran-Iraq War. He criticized U.S. presence in Iraq and his visit highlighted Iran's influence on Iraq, an influence against U.S. interests and efforts. ${ }^{113}$ Table 2 on the following page presents a select list of strategically timed coincidences that highlight Iran's attempts to defy international pressure on its nuclear program.

Table 2: Select and potential Iranian attempts to defy international pressure ${ }^{114}$

\begin{tabular}{|ll|}
\hline Date & Event \\
\hline Jun-03 & $\begin{array}{l}\text { Iran detained four US soldiers and one civilian before the first IAEA report on its nuclear } \\
\text { activities. }\end{array}$ \\
Nov-03 & $\begin{array}{l}\text { Ten days after signing an agreement with the EU-3, Khamenei condemned "the excessive } \\
\text { demands" from overseas in front of a large gathering of military and government officials. }\end{array}$ \\
The date Iran was suppose to respond to a P5+1 offer coincided with Hezbollah's attack \\
and kidnapping of Israeli soldiers, starting the Lebanon War.
\end{tabular}

From late 2011 onwards - especially following the assassination of Iranian missile architect Hassan Tehran Moghaddam and the IAEA's report on the possible military dimensions of Iran's nuclear program - Iran has taken a more offensive strategy against western pressures and covert attempts to undermine its nuclear program. ${ }^{115}$ The IRGC may have been involved in several assassination plots, including a plot to assassinate the Saudi ambassador on U.S. oil, and Iran has threatened to close the Straits of Hormuz or 
retaliate against Israel and American forces in the Middle East. ${ }^{116}$ In a recent testimony, Senator Joseph Lieberman commented that: "we now have the reappearance on a global scale of Iran-backed terrorism." 117 Similarly, Director of National Intelligence James Clapper has commented that "some Iranian officials - probably including Supreme Leader Ali Khamenei-have changed their calculus and are now more willing to conduct an attack in the United States in response to real or perceived US actions that threaten the regime." 118,119 


\section{Summary of Iran's divide, delay, and defy tactics}

Overall, this paper outlined the three main types of bargaining tactics Iran has used to protect its nuclear program. Table 3 summarizes the particular tactics within each category. While this paper distinguishes between tactics that allow Iran to divide, delay, or defy, there is more of a continuous spectrum between delay versus defy tactics and delay tactics are also acts of defiance and vice versa. The vertical columns denote what Iran was trying to prevent or subvert with its divide, delay, or defy tactic - international monitoring and detection, or international negotiations and commitments, or international sanctions and pressure.

Table 3: Summary of Iran's nuclear bargaining tactics

\begin{tabular}{|l|l|l|l|}
\hline Divide & \multicolumn{1}{|c|}{$\begin{array}{c}\text { Monitoring \& } \\
\text { Detection }\end{array}$} & \multicolumn{1}{|c|}{$\begin{array}{c}\text { Negotiations \& } \\
\text { Commitments }\end{array}$} & \multicolumn{1}{c|}{$\begin{array}{c}\text { Sanctions \& } \\
\text { Pressure }\end{array}$} \\
\hline Delay & $\begin{array}{l}\text { Creates hurdles and stalls } \\
\text { requests; }\end{array}$ & $\begin{array}{l}\text { Worked with the EU-3 (2003-2005), Russia \& China } \\
\text { (2005-present), Brazil \& Turkey (2010), and other actors }\end{array}$ \\
\hline & $\begin{array}{l}\text { Frames talks by setting } \\
\text { agenda, preconditions, } \\
\text { venue, and location; } \\
\text { information but updates } \\
\text { based on detection }\end{array}$ & $\begin{array}{l}\text { Negotiates and responds } \\
\text { slow to offers } \\
\text { hope'/concessions before } \\
\text { international events; }\end{array}$ & $\begin{array}{l}\text { Adopts temporary and } \\
\text { shifting positions }\end{array}$ \\
\hline Defy & $\begin{array}{l}\text { Stopped implementing AP } \\
\text { and Code 3.1 of Subsidiary } \\
\text { Arrangements; }\end{array}$ & $\begin{array}{l}\text { Uses legalistic } \\
\text { interpretations to find } \\
\text { loopholes and minimize } \\
\text { commitments; }\end{array}$ & $\begin{array}{l}\text { Argues for international right } \\
\text { to enrich uranium; }\end{array}$ \\
\hline & $\begin{array}{l}\text { Modifies and razes } \\
\text { suspected sites }\end{array}$ & $\begin{array}{l}\text { Renegotiates and rejects } \\
\text { previous agreements }\end{array}$ & $\begin{array}{l}\text { Proclaims fatwa against } \\
\text { nuclear weapons; }\end{array}$ \\
\hline & & $\begin{array}{l}\text { Demonstrates nuclear } \\
\text { capability and resolve; }\end{array}$ \\
\hline
\end{tabular}

\section{Iran's Current Nuclear Bargaining Capability}

While Iran still embraces all three types of bargaining tactics, the international community is more aware of Iran's behavior. Iran faces increasing difficulty implementing previous tactics and is innovating and searching for new bargaining leverages.

First, Iran may be reaching a limit on employing key international actors - Europe, Russia, and China - to block international sanctions. Iran has exhausted its ability to divide Europe from the United States in international negotiations. From 2006 to 2010, Russia and China slowly acquiesced to Western pressure for more sanctions against Iran. While Russia and China have not supported any UNSC sanctions on Iran from mid-2010 onwards and oppose unilateral sanctions on Iran, both countries are not actively campaigning to rollback imposed sanctions. Both, though, strongly oppose any military action against Iran. Since the range of imposed sanctions - as well as the covert war on Iran's nuclear program - are having a tremendous domestic impact on Iran, Tehran is engaging in a diplomatic offense to reach out to the Non-Aligned Movement (NAM) and to divert a select other countries, including Pakistan, Iraq, and Egypt, away from the United States. ${ }^{120}$ 
Second, Iran is less capable of delaying international monitoring, negotiations, and pressure. Tehran's repeated failure to disclose its nuclear development in a timely manner to the IAEA has prompted greater scrutiny and intelligence efforts to scrutinize, detect, and uncover Iran's nuclear capabilities. The P5+1 are also less willing to give Iran benefit of the doubt. In the first eight months of 2012, there were as many P5+1 meetings as in the previous two years. The P5 +1 pressed for firmer deadlines and are less overly optimistic when Iran provides strategically timed concessions to derail international sanctions.

Third, as its options for divide and delay have waned, Iran is relying more on defy tactics. Iran considered enriching HEU for naval reactors and warned of closing the Straits of Hormuz. Tehran is fueling unrest and anti-American sentiment in Afghanistan, building and training militia in Syria, and engaged in terrorist acts against the West. ${ }^{121}$

Domestic power struggles between multiple power centers have further contributed to Iran's defiant behavior. The politicization of nuclear issues has made it difficult for Iranian leaders to appear soft on nuclear issues and made it easier for leaders to take nationalistic and tougher stances. Ahmadinejad's contradictory efforts to undermine Khamenei's attempts to either negotiate or stand tough and firm against the West has also complicated the international community's dialogue with Iran, making reaching mutually beneficial positions difficult.

Iran's ability to defy western pressures, however, may diminish over time. Domestically, sanctions have increased tensions and led to significant inflation. Iran has taken extreme measures, including banning broadcasted images of chicken - unaffordable to most - to prevent social unrest. ${ }^{122}$ Regionally, Syria, Iran's closest ally, has become the battleground for a proxy war: supported by western and Arab countries, Syrian rebels are pitted against their government, which Iran backs and which wields Russian arms. ${ }^{123}$ It is far from clear that the Syrian regime can hold on to power, and Iran may lose a key partner in its "Axis of Resistance." Iran's ties to terrorist groups Hezbollah and Hamas have also weakened. Hamas is increasingly influenced by Egypt's Muslim Brotherhood, and Hezbollah has become a ruling party in Lebanon concerned with its electoral interests. ${ }^{124}$

While Iran's range of bargaining options has narrowed and its leaders have employed more acts of defiance, it is still possible to prevent greater confrontation between Iran and the West. Indeed, Ali Akbar Velayati, a close foreign policy advisor to Khamenei, has indicated that Khamenei - and most likely other Iranian leaders too - "recognizes that Syria's Bashar al-Assad will eventually be toppled in Syria" and "does not want the end of his legacy in Iranian history books to be having brought economic hardship to the Iranian people." $" 125$ 
Notes

${ }^{1}$ GOV/2012/23: Implementation of the NPT Safeguards Agreement in the Islamic Republic of Iran, para. 10.

${ }^{2}$ GOV/2012/23: Implementation of the NPT Safeguards Agreement in the Islamic Republic of Iran, para. 13-24.

${ }^{3}$ GOV/2012/23: Implementation of the NPT Safeguards Agreement in the Islamic Republic of Iran, para. 11.

${ }^{4}$ Khatami even considered easing tensions with Israel, see Kaye, Nader, and Roshan, Israel and Iran: A Dangerous Rivalry.

${ }^{5}$ In late 2003, Iranian's decision to halt its covert nuclear weapons program and place its civilian nuclear program under IAEA scrutiny likely included at least four dimensions. First, Iran's regional adversary, Iraq, had collapsed under U.S. attack. From the 1980s to 2003, Iraq was Iran's primary threat and the Iran-Iraq War from 1980 to 1988 had claimed the lives of approximately one million Iranians. Iran's nuclear weapons program started in the mid1980s during the Iran-Iraq War after Iraq began trying to develop nuclear weapons. With the collapse of Iraq, there was less of a need for nuclear weapons to counter a regional adversary. See Vick, "Blame Saddam: Another Way of Seeing Iran's Nuclear Program.”; Black, "Iran and Iraq Remember War That Cost More Than a Million Lives."

Second, there was fear that the United States might invade Iran next and Iran's should not encourage U.S. military action. In April 2003, Iran was surrounded by American forces. Khatami candidly remarked, "they tell us that Syria is the next target, but according to our reports, Iran could well follow." North Korea, the third member of Bush's 'Axis of Evil' along with Iraq and Iran, was similarly fearful of U.S. force and met with Chinese and U.S. negotiators in April 2003 to announce that Pyongyang possessed nuclear weapons but would be willing to drop its nuclear program if the U.S. signed a non-aggression pact with North Korea. Responding in parallel, Iran offered the United States a grand bargain in May 2003. When the Bush administration rejected both North Korea and Iran's offers, there was even concern in Iran that the U.S. was interested in regime change. See Bowman, "The 'DemandSide': Avoiding a Nuclear Armed Iran," 633.; Sanger, "North Korea Says It Now Possesses Nuclear Arsenal."

Third, Iran's decision to halt its nuclear weapons program and cooperate with the IAEA may have also been motivated by Iran's attempt to undermine the Bush administration's lobbying of the IAEA. The United States wanted the IAEA to determine that Iran was in non-compliance with the NPT and refer Tehran to the United Nations Security Council. A referral to the Security Council would have opened the possibility of multilateral sanctions and more coercive measures. See Goodman and Bowen, "Behind Iran's Nuclear Weapons 'Halt'."

Finally, Libya's decision to secretly approach the United States in March 2003 to give up its nuclear weapon program may have also influenced Iranian decisions. Leaders in Tehran may have offered its grand bargain in May 2003 to mirror Libyan efforts or out of fear that Iran's nuclear work may be exposed following Libya's revelation. (The February 2007 IAEA Board of Governors report noted that there was uranium contamination on Iran's centrifuge equipment similar to the particles found in Libya. While this suggests that Pakistan supplied similar equipment to Libya, it could also suggest Iranian-Libyan nuclear cooperation. See GOV/2007/8: Implementation of the NPT Safeguards Agreement in the Islamic Republic of Iran, para. 15.)

${ }^{6}$ Statement by the Legal Adviser to the IAEA Board of Governors.

${ }^{7}$ Parsi, A Single Role of the Dice, 2-3.; "Iran Memo to the U.S."

${ }^{8}$ According to Seyed Houssein Mousavian, one of the key nuclear negotiators in the Khatami regime, the EU-3 wrote to the Iranian government to adopt the Additional Protocol to "help Iran build confidence with the international community about the peaceful nature of its nuclear program, particularly if Iran took measures to implement the Additional Protocol even before its formal ratification." (See Mousavian, The Iranian Nuclear Crisis: A Memoir, 70.) Then Chairman of the Expediency Council Hashemi Rafsanjani, however, warned:

without America on board, the Europeans would not be willing or able to make a final deal with Iran on the nuclear issue and therefore could use negotiations only to buy time and provide stopgap measures rather than resolving the issue. [...] implementation of the Additional Protocol with reservations would be possible along with very short-term suspension as confidence-building measures, but that if this did not suffice, negotiations would fail because Iran would not accept long-term suspension (Mousavian, 95).

${ }^{9}$ Farhi, “'Atomic Energy Is Our Assured Right': Nuclear Policy and the Shaping of Iranian Public Opinion,” 6-9.

${ }^{10}$ Ibid., 9.

${ }^{11}$ Yaphe and Lutes, Reassessing the Implications of a Nuclear-Armed Iran, 6.

${ }^{12}$ For an example of IAEA discussions of Iranian failures, see GOV/2004/83: Implementation of the NPT Safeguards Agreement in the Islamic Republic of Iran, para. 86.

${ }^{13}$ Yaphe and Lutes, Reassessing the Implications of a Nuclear-Armed Iran, 6. 
${ }^{14}$ According to Hassan Fereydoun Rowhani, Iran's chief nuclear negotiator from 2003 to 2005, the decision to begin operations at Isfahan pre-dated Ahmadinejad's tenure as president, see Sahimi, "Q\&A: Former Iran Nuclear Negotiator: Bush Negotiation Bid Was Rebuffed."

${ }^{15}$ Farhi, “"Atomic Energy Is Our Assured Right': Nuclear Policy and the Shaping of Iranian Public Opinion,” 12.; Porter, NIAC Memo: The Suspension Precondition: Lessons from Past EU-Iran Negotiation.

${ }^{16}$ Sahimi, "Q\&A: Former Iran Nuclear Negotiator: Bush Negotiation Bid Was Rebuffed."

${ }^{17}$ Coats and Robb, Meeting the Challenge: U.S. Policy Toward Iranian Nuclear Development, 51.

18 "History of Official Proposals on the Iranian Nuclear Issue."; Pellaud, Testing Alternative Approaches, 51.; Krause and Mallory, The Strategic Implications of the Iranian Nuclear Program, 16-17.

${ }^{19}$ INFCIRC 711: Communication Dated 27 August 2007 from the Permanent Mission of the Islamic Republic of Iran to the Agency Concerning the Text of the "Understandings of the Islamic Republic of Iran and the IAEA on the Modalities of Resolution of the Outstanding Issues."

${ }^{20}$ Pellaud, Testing Alternative Approaches, 56.; Coats and Robb, Meeting the Challenge: U.S. Policy Toward Iranian Nuclear Development, v.

${ }^{21}$ In December 2006, U.S. sent a second U.S. carrier task group to the Persian Gulf. By February 2007, press reports circulated that the Bush administration considered it "a real possibility" to attack Iran in 2007. The story was followed by another report that the U.S. may send a third carrier task group to the Persian Gulf and that "the presence of three carrier task groups in the Gulf simultaneously was the same level of U.S. striking power as the administration had in place during the air campaign against Iraq in 2003." On March 27, the United States began a naval exercise in the Gulf that "was the first joint naval and air operation since the air campaign against the Saddam Hussein regime." Two days later, Iran stopped implementing the Subsidiary Arrangement. An Iranian official noted that providing design information on its nuclear facilities would help the U.S. prepare for an attack on Iran. See Porter, "NIE Reveals Qom Facility Followed 2007 Bush Threats."

${ }^{22}$ The threat of U.S. attack on Iran diminished after the December 2007 release of the U.S. National Intelligence Estimate that Iran had halted its nuclear weapons program in 2003. See "As the Enrichment Machines Spin on: How America's Own Intelligence Services Have Brought International Policy on Iran to the Edge of Collapse"; "Ahmadinejad: U.S. Nuke Report a 'Victory' for Iran."

${ }^{23}$ Coats and Robb, Meeting the Challenge: U.S. Policy Toward Iranian Nuclear Development, 37.

${ }^{24}$ Iran may have either encouraged or at least not prohibited Hezbollah's actions to divert world attention away from Tehran's nuclear program. On July 11, 2006, Iran's top nuclear negotiator Ali Larijani discussed with European Union Foreign Secretary Javier Solona Iran's nuclear issues. That evening, Larijani flew to Damascus and met with Syrian President Bashar al-Assad, briefing him on mutual defense issues and Iran's nuclear talks. Larijani also talked to senior Hezbollah representatives the same night. The next day, Hezbollah launched its operation against Israel. Hezbollah's attack on Israel turned global attention at the July 15, 2006 St. Petersburg G8 summit to violence in Israel and Lebanon, diluting focus on Iran's nuclear issue. Interestingly, Hezbollah leader Sayyid Hassan Nasrallah has revealed that Hezbollah received \$300 million from Supreme Leader Khamenei for post-war compensation to families who suffered losses during the 2006 Lebanon War. See Timmerman, "Iran Ordered Attack on Israel, Official Says"; "Is An Iranian Official Behind Hezbollah's Attacks on Israel?"; "Exclusive: Iran Was Behind Hezbollah-Israel War"; Landau, Iran After the Lebanon War: Same Nuclear Ambitions, Different Regional Context; Coats and Robb, Meeting the Challenge: U.S. Policy Toward Iranian Nuclear Development, 34.; SaadGhorayeb, "Hezbollah's Iran Money Trail: It's Complicated.”; Dawson, “A Constructivist Approach to the USIranian Nuclear Program," 121.

Iran may have also wished to use its leverage over Hezbollah to gain time for its nuclear program.

Commenting after the Lebanon War, Perkovich notes: "This suggests that diplomatic maneuvers in the coming months will converge around an implicit compromise in which Iran does not cause problems in one area in return for not being pressed on the other. Most likely, Iran will limit its re-supply of advanced weaponry to Hezbollah and endorse Hezbollah's cooperation with the Lebanese Army and an international force patrolling the zone between Lebanon and Israel, in tacit exchange for further Security Council dithering as Iran continues its uraniumenrichment activities, free from sanctions." (See Perkovich, "Iran's Lebanon Card.")

${ }^{25}$ Katzman, Iran's Activities and Influence in Iraq, 2.

${ }^{26}$ Ahmadinejad's efforts were also supported by Khamenei, who say politicizing Iran's nuclear program as a way to discredit the reformists who were more willing to negotiate with the West on the nuclear issue. See Chubin, "The Domestic Politics of the Nuclear Question in Iran," 76.

${ }^{27}$ Bowman, "The 'Demand-Side': Avoiding a Nuclear Armed Iran," 635. 
${ }^{28}$ One of the telling accounts of fraud is that an Iranian official accused Larijani, speaker of the majles, of calling Moussavi before the election polls had closed. The parliament member criticized Larijani for giving that information to Mousavi since Larijani had "firsthand access to top secret information," See "MP: Larijani Provoked Mousavi."

${ }^{29}$ Katzman, Iran: U.S. Concerns and Policy Responses, 11-12.

${ }^{30}$ According to one account, "the president and other conservatives (among others, the Army Chief of Staff Hassan Firouzabadi) had approved the Vienna solution; the "moderate forces" (Mousavi, Larijani) rejected it, probably out of tactical considerations in order to deny the president a diplomatic success. The domestic backlash forced the Supreme Leader and the president to backtrack and to formulate a counterproposal that would see the fuel swap occur simultaneously with the delivery of the fresh TRR fuel, much later, an option sensibly rejected by the U.S.." See Pellaud, Testing Alternative Approaches, 53-54.

${ }^{31}$ Ahmadinejad, for example, indicated that Iran was interested in a nuclear fuel swap on September 13, 2011, only two weeks after Fereydoun Abbasi-Davani, Head of Iran's Atomic Energy Organization, had announced that Iran would never halt its domestic production of $20 \%$ enriched uranium and was no longer interested in a fuel swap. See "Abbasi-Davani Interview on Iran's 20 Percent Enrichment"; Weymouth, "An Exclusive Interview with Mahmoud Ahmadinejad"; Kristof, "An Interview with Mahmoud Ahmadinejad."

${ }^{32}$ Ahmadinejad's actions may be "designed to make the negotiations with P $5+1$ fail because they are being led by the Revolution's Leader while the administration is sidelined." The administration criticized Iranian nuclear negotiators for being too soft, claiming that "Jalili, during his bilateral talks with Ashton, asked 100 times for a delay in oil sanctions". Ahmadinejad also became the first Iranian president to visit to Abu Musa Island, a disputed island that Iran claims ownership over, immediately before the P5+1 April 2012 talks in Istanbul, Turkey. The visit rallied nationalism but also intensified tensions between Iran and Arab countries. The visit may have intended to upstage the P5+1 talks in two ways: (1) giving Ahmadinejad popular attention to detract from the P5+1 talks and (2) potentially complicating the $\mathrm{P} 5+1$ talks by eliciting more Arab pressure on Western negotiators to take a harder stance against Iran. See Amirahmadi and Shahidsaless, "Nuclear Talks: Factional Infighting in Tehran and Miscalculations in Washington"; Erdbrink, "A Tiny Island Is Where Iran Makes a Stand."

${ }^{33}$ Nabili, "Mousavi Revives Reformist Vote."

${ }^{34}$ Fathi, "Iranian Opposition Leader Warns Against Sanctions."

${ }^{35}$ Moradi, "IRGC Backs Down from Threats to Close Strait of Hormuz"; "100 Iranian MPs Call for Strait of Hormuz to Be Blocked"; "Top Commander: Hormuz Strait Closure Plan Ready for Action"; "Iran Tests Upgraded Version of Short-range Missile"; "Iran Holds Air Defence Drills."

${ }^{36}$ Dareini, "Iran Parliamentarians Call for Nuclear Ships."

${ }^{37}$ While many warn that Iran will enrich uranium to higher levels if the country faces greater threats, Iran's acting Navy Commander has indicated that Iran currently has no plans to produce highly enriched nuclear fuel for naval reactors. See "Khamenei Aide: Iran Will Increase Enrichment If World Pressure Persists."; "Report: Navy Commander Says Iran Has No Immediate Plan for Building Naval Reactors."

${ }^{38}$ A former Russian prime minister also noted that he feared Iran might make nuclear weapons if Israel attacks Iran. See "Iran to Make Own WMD If Israel Delivers Airstrike - Expert."

39 "Iran Commander: We Have Reached a Fateful Stage."

${ }^{40}$ Tait, "Ayatollah Ali Khamenei Criticises Attack on British Embassy."

41 "Imam Khamenei Meets with University Students and Elite Academicians."

42 "Senior Iranian Cleric Slams Media Restrictions."

${ }^{43}$ Speaking to the country's clerics, Rafsanjani noted, "we can still pass this critical juncture if we act correctly and wisely, make our relations with the world softer and adopt a policy of détente. See "Former Iranian President: Adopt Detente Policy in Nuclear Dispute."

${ }^{44}$ Faucon, "Iran May Consider Nuclear Downgrade in Exchange For Ending Sanctions -Diplomat."

${ }^{45}$ LaFranchi, "Libya Fallout: Why Iran, North Korea Now Less Likely to Drop Nuclear Ambitions."

${ }^{46}$ Mousavian, The Iranian Nuclear Crisis: A Memoir, 87.

${ }^{47}$ Posch, "Iran and the European Union."

${ }^{48}$ Mousavian, The Iranian Nuclear Crisis: A Memoir, 87.

${ }^{49}$ Ibid., 107.

${ }^{50}$ Ibid., 117.

${ }^{51}$ Chubin, Iran's Nuclear Ambition, 69.

${ }^{52}$ Ibid., 106.

${ }^{53}$ China has maintained a lower profile but relatively consistent position on supporting Iran's rights to peaceful nuclear energy. Russia, however, worked harder to block sanctions against Iran under President Vladimir Putin 
(2004-2008, 2012-) than President Dmitry Medvedev. The 'reset' in diplomatic relations between Russia and the United States during the Obama administration has encouraged President Medvedev to be more willing to work with the U.S. on Iran. During the Putin administration, for example, Russia negotiated with Iran short-range Tor-M1 surface-to-air missile systems in 2005 and the S-300 air defense contract in 2007. Both systems help protect Iran's nuclear facilities from an Israeli or U.S. attack. Parker, Russia and the Iranian Nuclear Program: Replay or Breakthrough?, 4.

${ }^{54}$ Chubin, Iran's Nuclear Ambition, 106.

${ }^{55}$ Russia's ambassador to the UN, Vitaly Churkin, told reporters, "We do not want to ambush Iran in any way. We're very much in a negotiating political mode. We do not want to dictate things to Iran." Similarly, Russian Foreign Minister Sergei Lavrov noted, "If after a certain period we don't hear an answer from Iran and discussions aren't renewed, we will look in the Security Council at additional measures." See Harvey and Sabatini, "Russia's Lukewarm Support for International Sanctions Against Iran: History and Motivations."

${ }^{56}$ Ibid.

${ }^{57}$ Garver, China s Iran Policies, 7.

${ }_{58}^{58}$ Ibid., 6.

${ }^{59}$ Parker, Russia and the Iranian Nuclear Program: Replay or Breakthrough?, 1.

${ }^{60}$ Ibid., 43.

${ }^{61}$ Garver, China's Iran Policies, 6.

${ }^{62}$ According to Mousavian, ElBaradei interpreted for Iran that "suspension need only apply to the introduction of nuclear material into centrifuges, and not all enrichment related activities." See Mousavian, The Iranian Nuclear Crisis: A Memoir, 109.

${ }^{63}$ Landau, Decade of Diplomacy: Negotiations with Iran and North Korea and the Future of Nuclear Nonproliferation, 36 .

${ }^{64}$ Recognizing Iran as a Strategic Threat: An Intelligence Challenge for the United Stated, 13.

${ }^{65}$ According to ElBaradei, North Korea "had walked out of the NPT and made explicit threats about developing nuclear weapons (and would in fact test its first weapon less than three months later, in October 2006), yet the Americans were ready to join them in direct dialogue." See The Age of Deception: Nuclear Diplomacy in Treacherous Times, 203.

${ }^{66}$ Parsi, A Single Role of the Dice, 295.

67 "Russia Urges Iran to Cooperate with UN on Nuclear Program"; "China Urges Closer Cooperation from Iran in Nuclear Standoff."

${ }^{68}$ List of Revelations on Iran's Nuclear \& WMD Activities by the Iranian Opposition Since 2002.

${ }^{69}$ Parsi, A Single Role of the Dice, 124.

${ }^{70}$ Albright, Stricker, and Walrond, IAEA Iran Safeguards Report, 4.

${ }^{71}$ Albright and Shire, IAEA Report on Iran.

${ }^{72}$ Kerr, "IAEA to Visit Two 'Secret' Nuclear Sites in Iran."

${ }^{73}$ List of Revelations on Iran's Nuclear \& WMD Activities by the Iranian Opposition Since 2002.; Ferguson and Boureston, "Focus on Iran's Laser Enrichment Program."

${ }_{74}^{74}$ Delpech, How Much Time Is Left for a Diplomatic Solution, 35.

${ }^{75}$ Ibid., 39.

${ }^{76}$ Landau, Decade of Diplomacy: Negotiations with Iran and North Korea and the Future of Nuclear Nonproliferation, 58.

${ }^{77}$ The modalities plan further included an understanding that once issues were closed, it would no longer be open to revisiting: "The Agency agreed to provide Iran with all remaining questions according to the above work plan. This means that after receiving the questions, no other questions are left. Iran will provide the Agency with the required clarifications and information." In addition, the plan was constructed to "cover all remaining issues and the Agency confirmed that there are no other remaining issues and ambiguities regarding Iran's past nuclear program and activities." See INFCIRC 711: Communication Dated 27 August 2007 from the Permanent Mission of the Islamic Republic of Iran to the Agency Concerning the Text of the "Understandings of the Islamic Republic of Iran and the IAEA on the Modalities of Resolution of the Outstanding Issues."

${ }_{78}^{78}$ Rozen, "Iran Complains over Preparations for Moscow Nuclear Talks."

${ }^{79}$ Katzman, Iran: U.S. Concerns and Policy Responses, 18-19.

${ }^{80}$ Principles for Negotiating with Iran, 7.

${ }^{81}$ Sciolino and Slackman, "Before Nuclear Regulators' Meeting, Iran Allows Inspectors Access to One Site." See also GOV/2006/15. 27 February 2006, para. 35. 
82 "Iran Suspected of Increasing Covert Nuclear Work at Military Site."

${ }^{83}$ Landau, Decade of Diplomacy: Negotiations with Iran and North Korea and the Future of Nuclear Nonproliferation, 56.

${ }^{84}$ Chubin, Iran's Nuclear Ambition, 106.

${ }^{85}$ According to one account, senior hard-line cleric Ayatollah Ahmad Khatami described the Geneva talks as a victory for Iran: "Prior to the talks, [the West] used to speak of suspension and sanctions against Iran but after the talks, there has not been any word of suspension or sanctions. Rather, Iran's package of proposals was the axis." See Parsi, A Single Role of the Dice, 131.

${ }^{86}$ Cooper and Broad, "Russia and China Endorse Agency's Rebuke of Iran."

${ }^{87}$ Nuclear Sites: Kalaye Electric Company.

${ }^{88}$ GOV/2003/63: Implementation of the NPT Safeguards Agreement in the Islamic Republic of Iran, 7.

${ }^{89}$ GOV/2004/83: Implementation of the NPT Safeguards Agreement in the Islamic Republic of Iran, 8.

${ }^{90}$ After being inspected by the IAEA, Farayand Technique Company changed its name to Technology of Centrifuge of Iran Company and its address to Saadat Abad. Similarly, Pars Trash changed its name to Rah Avard Kalaey Iran Company. See Iranian Entity: Pars Trash Company; Iranian Entity: Farayand Technique.

${ }^{91}$ GOV/2006/53: Implementation of the NPT Safeguards Agreement in the Islamic Republic of Iran, para. 24.; Rubin, "Nations Move Closer to Unity on Iran Strategy."; Kerr, "IAEA Raises New Questions on Iran Program."

${ }_{92}$ Albright, Brannan, and Stricker, The Physics Research Center and Iran's Parallel Military Nuclear Program.

${ }^{93}$ Hibbs, Iran and the IAEA Talk Again.

94 Ibid.

${ }^{95}$ Albright and Avagyan, Robert, Activity at Parchin Explosive Testing Site Continues: Time Running Out for a Sound IAEA Inspection.

${ }^{96}$ GOV/2012/23: Implementation of the NPT Safeguards Agreement in the Islamic Republic of Iran, para. 45.

${ }^{97}$ Albright, Stricker, and Walrond, IAEA Iran Safeguards Report, 4.

${ }^{98}$ Mousavian, The Iranian Nuclear Crisis: A Memoir, 124.

${ }^{99}$ Ibid., 126.

${ }^{100}$ In exchange for the new agreement, the EU3 "promised to do its best to normalize Iran-IAEA relations and close Iran's nuclear dossier in the June meeting of the Board of Governors." See Ibid., 126-127.

${ }^{101}$ Ibid., 134.

102 Ibid.

${ }^{103}$ The U.K. Foreign and Commonwealth office responded to Iran's announcement of its new facility with disappointment: "This announcement sends the wrong signal about Iranian willingness to implement a suspension of nuclear enrichment-related activities. It will make it more difficult for Iran to re-establish international confidence in her undertakings." See Response to the Iranian Announcement on Its Nuclear Facility in Esfahan.

${ }^{104}$ GOV/2004/34: Implementation of the NPT Safeguards Agreement in the Islamic Republic of Iran, para. 14.

105 The IAEA expressed its objection to the facility's operations: "In a letter dated 29 April 2004, Iran informed the Agency that it intended to conduct hot tests of the UF6 production line at UCF. On 7 May 2004, the Agency wrote to Iran, informing it that, given the amounts of nuclear material involved, the hot testing of UCF with UF6 gas would technically amount to the production of feed material for enrichment processes." See GOV/2004/34. Implementation of the NPT Safeguards Agreement in the Islamic Republic of Iran, para. 14.

106 "Diplomats: Iran Violating Spirit of Freeze."

107 The freeze was far from a freeze on all Iranian nuclear development. Iran continued construction of its Arak heavy-water plant. Since uranium mining was not explicitly included in the suspension, Iran also worked on its mines, particularly the Saghand mine in Yazd and the Gehine mine near Bandar Abbas. By July 2004, mining operations started in Gehine and a test quantity of yellowcake has been produced at the mill from mined ore. See Albright, “Appendix B: Iran's Nuclear Program: Status, Risks, and Prospects,” 60.

${ }^{108}$ Mousavian, The Iranian Nuclear Crisis: A Memoir, 179.

${ }^{109}$ Dahl, "Iran Submarine Plan May Fuel Western Nuclear Worries."

110 "Iran Says Security Council Demand Illegal"; "UN Security Council Dictating to IAEA on Iran Case, Illegal."

${ }^{111}$ Saunders, Case Study: Iran, Islam, the NPT, and the Bomb; Shuster, "Iran's Nuclear Fatwa: A Policy Or A Ploy?"; Bacaltos, "Potential Change in Iran's Nuclear Fatwa?"; "Bombs and Truth."

112 Porter, "Understanding Iran's Diplomatic Strategy."

${ }^{113}$ Ahmadinejad's visit to Iraq was initially scheduled in late March but was likely moved up to occur after the UNSC Resolution was passed and to further irritate the U.S. See "Iran President on Landmark Iraq Visit."; “Iran's Ahmadinejad May Visit Baghdad by Late March." 
114 "Iran Cleric Warns the West over Atomic Pressure." Tait, "Kidnappings Came Day Before UN Resolution." Tavernise, "Russia, Turkey and Iran Meet, Posing Test for U.S." Dawson, "A Constructivist Approach to the USIranian Nuclear Program," 120., Delpech, How Much Time Is Left for a Diplomatic Solution, 41. "Iran 'Planning 10 New Uranium Enrichment Sites'." "Iran Increases Number of Centrifuges."; "Iran's Supreme Leader Says Westernled Sanctions, Pressure, Won't Force Nuclear Policy Shift." Segall, "Iran Takes Off the Gloves."

${ }^{115}$ Segall, "Iran Takes Off the Gloves."

${ }^{116}$ Byman, Iran's Support for Terrorism in the Middle East; Johnson, "Iran Threatens To Torpedo US Carriers In The Persian Gulf."

${ }^{117}$ Guarino, "Lieberman: Iran Using Terror in Response to Western Nuclear Pressure."

${ }^{118}$ Clapper, Unclassified Statement for the Record on the Worldwide Threat Assessment of the US Intelligence Community for the Senate Select Committee on Intelligence.

${ }^{119}$ Iran, however, has backed away from closing the Straits of Hormuz by late July. The acting commander of the Revolutionary Guard naval forces announced that Iran plans to retain "intelligent control" of the waterway and that the Supreme Leader has the authority to close the waterway. See Moradi, "IRGC Backs Down from Threats to Close Strait of Hormuz."

${ }^{120}$ Walberg, "From OIC to NAM: Iran's Peace Offensive.", Haroon, "Iran and Pakistan Keep Working on IPI Gas Pipeline Project."

${ }^{121}$ Nichols, "Syria Conflict: Iran Supplies Arms To Assad Regime, U.N. Says"; Londoño, "Iran Intensifies Efforts to Influence Policy in Afghanistan"; Shanker, Schmitt, and Rubin, "U.S. Sees Iran in Bids to Stir Unrest in Afghanistan."

${ }^{122}$ Javedanfar, "Iran's Big Crisis: The Price of Chicken."

${ }^{123}$ Dergham, "The New Balance of Power in Syria Alters the Political Equation."

${ }^{124}$ Iran's key nuclear negotiator and close aide to Khamenei, Saeed Jalili, recently visited Lebanon shore up relations with Hezbollah. Hezbollah's potential shift away from Syria and Iran can also be seen in its relative lack of overt support to Syria. See Pfeffer, "As Western Diplomacy Dithers, Iran's Foreign Policy Chief Chases Lebanese Support."; Murphy, "Syria Captive Rift: Iran Defiant, Hezbollah Silent."

${ }_{125}^{12}$ Rozen, "Key Advisor to Supreme Leader May Seek Iran Presidency."

\section{Bibliography}

“100 Iranian MPs Call for Strait of Hormuz to Be Blocked.” Tehran Times, July 3, 2012. http://www.payvand.com/news/12/jul/1023.html.

“Abbasi-Davani Interview on Iran's 20 Percent Enrichment.” ISIS Iran in Brief, August 31, 2011. http://www.isisnucleariran.org/brief/detail/abbasi-davani-interview-on-irans-20-percent-enrichment/.

“Ahmadinejad: U.S. Nuke Report a 'Victory' for Iran.” Associated Press, December 5, 2007. http://www.msnbc.msn.com/id/22110891/ns/world_news-mideast_n_africa/t/ahmadinejad-us-nuke-reportvictory-iran/.

Albright, David. “Appendix B: Iran's Nuclear Program: Status, Risks, and Prospects.” In Reassessing the Implications of a Nuclear-Armed Iran, 53-71. McNair Paper 69. Washington, D.C.: National Defense University Press, 2005.

Albright, David, and Avagyan, Robert. Activity at Parchin Explosive Testing Site Continues: Time Running Out for a Sound IAEA Inspection. ISIS Reports, July 2, 2012. http://isis-online.org/isis-reports/detail/activity-atparchin-explosive-testing-site-continues-time-running-out-for-a/.

Albright, David, Paul Brannan, and Andrea Stricker. The Physics Research Center and Iran's Parallel Military Nuclear Program. Washington, D.C.: Institute for Science and International Security, February 23, 2012. http://isis-online.org/uploads/isis-reports/documents/PHRC_report_23February2012.pdf.

Albright, David, and Jacqueline Shire. IAEA Report on Iran. Washington, D.C.: Institute for Science and International Security, November 16, 2009. http://isis-online.org/isis-reports/detail/iaea-report-on-iranfordow-enrichment-plant-at-advanced-stage-of-constructi/.

Albright, David, Andrea Stricker, and Christina Walrond. IAEA Iran Safeguards Report. Washington, D.C.: Institute for Science and International Security, February 25, 2011. http://isis-online.org/uploads/isisreports/documents/IAEA_Iran_Safeguards_Report_ISIS_analysis_25Feb2011_final-new.pdf. . ISIS Analysis of IAEA Iran Safeguards Report. Washington, D.C.: Institute for Science and International Security, May 25, 2012. 
Amirahmadi, Hooshang, and Shahir Shahidsaless. "Nuclear Talks: Factional Infighting in Tehran and Miscalculations in Washington." American Iranian Council, May 11, 2012. http://usiran.org/content/nuclear-talks-factional-infighting-tehran-and-miscalculations-washington.

"As the Enrichment Machines Spin on: How America's Own Intelligence Services Have Brought International Policy on Iran to the Edge of Collapse." The Economist, January 31, 2008. http://www.economist.com/node/10601584.

Bacaltos, Lyle. "Potential Change in Iran's Nuclear Fatwa?" ISIS Iran in Brief, August 2, 2012. http://www.isisnucleariran.org/brief/detail/potential-change-in-irans-nuclear-fatwa/.

Black, Ian. "Iran and Iraq Remember War That Cost More Than a Million Lives." The Guardian, September 23, 2010. http://www.guardian.co.uk/world/2010/sep/23/iran-iraq-war-anniversary.

"Bombs and Truth." The Economist, May 19, 2012. http://www.economist.com/node/21555541.

Bowman, Bradley. "The 'Demand-Side': Avoiding a Nuclear Armed Iran.” Orbis, no. Fall 2008 (2008): 627-642.

Byman, Daniel. Iran's Support for Terrorism in the Middle East. Washington, D.C, 2012.

"China Urges Closer Cooperation from Iran in Nuclear Standoff." Reuters, February 12, 2012. http://www.reuters.com/article/2012/02/13/us-china-iran-idUSTRE81C07X20120213.

Chubin, Shahram. Iran's Nuclear Ambition. Washington, D.C.: Carnegie Endowment for International Peace, 2006. . "The Domestic Politics of the Nuclear Question in Iran." In The Strategic Implications of the Iranian Nuclear Program, edited by Charles Mallory and Joachim Krause, 72-81. Berlin, Germany: Aspen European Strategy Forum, n.d.

Clapper, James. Unclassified Statement for the Record on the Worldwide Threat Assessment of the US Intelligence Community for the Senate Select Committee on Intelligence. Washington, D.C: Senate Select Committee on Intelligence, January 31, 2012. http://www.washingtonpost.com/wp-srv/world/documents/james-clappersenate-testimony.html.

Coats, Daniel, and Charles Robb. Meeting the Challenge: U.S. Policy Toward Iranian Nuclear Development. Washington, D.C.: Bipartisan Policy Center, September 2008. http://bipartisanpolicy.org/sites/default/files/us\%20policy\%20toward\%20iranian\%20nuclear\%20developm ent.pdf.

Cooper, Helene, and William Broad. "Russia and China Endorse Agency's Rebuke of Iran.” New York Times, November 27, 2009. http://www.nytimes.com/2009/11/28/world/28nuke.html.

Dahl, Fredrik. "Iran Submarine Plan May Fuel Western Nuclear Worries." Reuters, July 5, 2012. http://www.reuters.com/article/2012/07/05/us-iran-nuclear-submarines-idUSBRE8640PC20120705.

Dareini, ali Akbar. "Iran Parliamentarians Call for Nuclear Ships." Associated Press, July 15, 2012. http://www.google.com/hostednews/ap/article/ALeqM5hOjrssj7e0moWAvbBDVnxEIShI8Q?docId=36b75 $7 \mathrm{cf} 09 \mathrm{cc} 445 \mathrm{c} 9 \mathrm{e} 711564 \mathrm{a} 1 \mathrm{~b} 662 \mathrm{c} 2$.

Dawson, Julian. "A Constructivist Approach to the US-Iranian Nuclear Program". Master's Thesis, University of Calgary, 2012.

Delpech, Thérèse. How Much Time Is Left for a Diplomatic Solution. The Strategic Implications of the Iranian Nuclear Program. Berlin, Germany: Aspen European Strategy Group, 2010.

Dergham, Raghida. "The New Balance of Power in Syria Alters the Political Equation." The Huffington Post, August 3, 2012. http://www.huffingtonpost.com/raghida-dergham/the-new-balance-of-power_b_1739624.html.

"Diplomats: Iran Violating Spirit of Freeze." Associated Press, February 3, 2005. http://www.msnbc.msn.com/id/6906491.

ElBaradei, Mohamed. The Age of Deception: Nuclear Diplomacy in Treacherous Times. New York: Metropolitan Books, 2011.

Erdbrink, Thomas. “A Tiny Island Is Where Iran Makes a Stand.” New York Times, April 30, 2012. http://www.nytimes.com/2012/05/01/world/middleeast/dispute-over-island-of-abu-musa-unites-iran.html.

“Exclusive: Iran Was Behind Hezbollah-Israel War.” Iran Focus, August 16, 2006. http://www.iranfocus.com/en/?option=com_content\&task=view\&id=8256.

Farhi, Farideh. "“Atomic Energy Is Our Assured Right': Nuclear Policy and the Shaping of Iranian Public Opinion." In Nuclear Politics in Iran, edited by Judith Yaphe. Washington, D.C.: National Defense University Press, 2010. http://www.ndu.edu/press/lib/pdf/nuclear-politics-in-iran.pdf.

Fathi, Nazila. "Iranian Opposition Leader Warns Against Sanctions.” New York Times, October 1, 2009. http://www.nytimes.com/2009/10/02/world/middleeast/02iran.html. 
Faucon, Benoit. "Iran May Consider Nuclear Downgrade in Exchange For Ending Sanctions -Diplomat." The Wall Street Journal, August 4, 2012. http://online.wsj.com/article/BT-CO-20120804-700813.html.

Ferguson, Charles, and Jack Boureston. "Focus on Iran's Laser Enrichment Program." FirstWatch International, June 17, 2004. http://www.iranwatch.org/privateviews/First\%20Watch/perspex-fwi-Laser.pdf.

"Former Iranian President: Adopt Detente Policy in Nuclear Dispute." The Journal of Turkish Weekly, August 6, 2012. http://www.turkishweekly.net/news/139786/former-iranian-president-adopt-detente-policy-innuclear-dispute.html.

Garver, John. China's Iran Policies. Washington, D.C., 2011.

http://www.uscc.gov/hearings/2011hearings/written_testimonies/11_04_13_wrt/11_04_13_garver_testimo ny.pdf.

Goodman, Michael, and Wyn Q. Bowen. "Behind Iran's Nuclear Weapons 'Halt'." Bulletin of Atomic Scientists (February 19, 2008). http://www.thebulletin.org/web-edition/features/behind-irans-nuclear-weapons-halt.

GOV/2003/63: Implementation of the NPT Safeguards Agreement in the Islamic Republic of Iran. Board of Governors, IAEA, August 26, 2003. http://www.isisnucleariran.org/assets/pdf/iaea-iranreport-082603.pdf.

GOV/2004/34: Implementation of the NPT Safeguards Agreement in the Islamic Republic of Iran. Board of Governors, IAEA, June 1, 2004.

GOV/2004/83: Implementation of the NPT Safeguards Agreement in the Islamic Republic of Iran. Board of Governors, IAEA, November 15, 2004.

GOV/2006/53: Implementation of the NPT Safeguards Agreement in the Islamic Republic of Iran. Board of Governors, IAEA, August 31, 2006.

GOV/2007/8: Implementation of the NPT Safeguards Agreement in the Islamic Republic of Iran. Board of Governors, IAEA, February 22, 2007.

GOV/2012/23: Implementation of the NPT Safeguards Agreement in the Islamic Republic of Iran. Board of Governors, IAEA, May 25, 2012.

GOV/2012/9: Implementation of the NPT Safeguards Agreement and Relevant Provisions of Security Council Resolutions in the Islamic Republic of Iran. Vienna: IAEA, February 24, 2012.

Guarino, Douglas. "Lieberman: Iran Using Terror in Response to Western Nuclear Pressure." National Journal, July 12, 2012. http://www.nationaljournal.com/nationalsecurity/lieberman-iran-using-terror-in-response-towestern-nuclear-pressure-20120712.

Haroon, Agha Iqrar. "Iran and Pakistan Keep Working on IPI Gas Pipeline Project." Tehran Times, August 8, 2012. http://www.tehrantimes.com/economy-and-business/100399-iran-and-pakistan-keep-working-on-ipi-gaspipeline-project.

Harvey, Cole, and Richard Sabatini. "Russia's Lukewarm Support for International Sanctions Against Iran: History and Motivations." Nuclear Threat Initiative, April 15, 2010. http://www.nti.org/analysis/articles/russiassupport-sanctions-against-iran/.

Hibbs, Mark. Iran and the IAEA Talk Again. Washington, D.C.: Carnegie Endowment for International Peace, May 12, 2012. http://carnegieendowment.org/2012/05/12/iran-and-iaea-talk-again/apy9.

"History of Official Proposals on the Iranian Nuclear Issue." Arms Control Association, August 2012. http://www.armscontrol.org/factsheets/Iran_Nuclear_Proposals.

"Imam Khamenei Meets with University Students and Elite Academicians." AhlulBayt News Agency, August 9, 2012. http://abna.ir/data.asp?lang=3\&id=335429.

INFCIRC 711: Communication Dated 27 August 2007 from the Permanent Mission of the Islamic Republic of Iran to the Agency Concerning the Text of the "Understandings of the Islamic Republic of Iran and the IAEA on the Modalities of Resolution of the Outstanding Issues". IAEA, August 27, 2007. http://www.iaea.org/Publications/Documents/Infcircs/2007/infcirc711.pdf.

"Iran Cleric Warns the West over Atomic Pressure.” Washington Post, December 31, 2006. http://www.washingtonpost.com/wp-dyn/content/article/2006/12/31/AR2006123100171_pf.html.

"Iran Commander: We Have Reached a Fateful Stage." Jerusalem Post, August 3, 2012. http://www.jpost.com/IranianThreat/News/Article.aspx?id=279980.

"Iran Holds Air Defence Drills." NY Daily News, July 12, 2012. $\mathrm{http} / /$ india.nydailynews.com/business/f4f5e23035ee2ec9d21e777ea3f71378/iran-holds-air-defence-drills.

"Iran Increases Number of Centrifuges." Voice of Russia, July 25, 2012. http://english.ruvr.ru/2012_07_25/Iranincreases-number-of-centrifuges/. 
"Iran Increases Uranium Enrichment Activities." The Telegraph, July 25, 2012. http://www.telegraph.co.uk/news/worldnews/middleeast/iran/9425580/Iran-increases-uranium-enrichmentactivities.html.

“Iran Memo to the U.S.”, 2003. http://www.nytimes.com/packages/pdf/opinion/20070429_iran-memoexpurgated.pdf.

"Iran 'Planning 10 New Uranium Enrichment Sites'.” BBC News, November 29, 2009. http://news.bbc.co.uk/2/hi/middle_east/8385275.stm.

"Iran President on Landmark Iraq Visit." $C N N$, March 2, 2008. http://articles.cnn.com/2008-0302/world/iraq.ahmadinejad_1_iraqi-president-jalal-talabani-shiite-led-iraqi-government-iran-and-iraqshare? $\mathrm{s}=$ PM:WORLD.

"Iran Says Security Council Demand Illegal." Fars News Agency, August 1, 2006. http://english.farsnews.com/newstext.php?nn=8505100224.

"Iran Suspected of Increasing Covert Nuclear Work at Military Site." Associated Press, November 21, 2011. http://www.haaretz.com/news/middle-east/iran-suspected-of-increasing-covert-nuclear-work-at-militarysite-1.396834.

"Iran Tests Upgraded Version of Short-range Missile." USA Today, August 4, 2012. http://www.usatoday.com/news/world/story/2012-08-04/iran-missiles/56768478/1.

"Iran to Make Own WMD If Israel Delivers Airstrike - Expert.” RIA Novosti, August 8, 2012. http://en.rian.ru/world/20120808/175057044.html.

“Iran’s Ahmadinejad May Visit Baghdad by Late March.” Reuters. Tehran, February 10, 2008. http://www.reuters.com/article/2008/02/10/us-iran-iraq-ahmadinejad-idUSDAH03727620080210.

"Iran's Supreme Leader Says Western-led Sanctions, Pressure, Won't Force Nuclear Policy Shift." Associated Press, July 25, 2012. http://www.washingtonpost.com/world/middle_east/irans-supreme-leader-sayswestern-led-sanctions-pressure-wont-force-policy-shift/2012/07/25/gJQABcIO8W_story.html.

Iranian Entity: Farayand Technique. Washington, D.C.: Wisconsin Project on Nuclear Arms Control, September 4, 2007. http://www.iranwatch.org/suspect/records/Farayand-Technique.html.

Iranian Entity: Pars Trash Company. Washington, D.C.: Wisconsin Project on Nuclear Arms Control, September 4, 2007. http://www.iranwatch.org/suspect/records/pars-trash-company.html.

“Is An Iranian Official Behind Hezbollah's Attacks on Israel?" Fox News, August 2, 2006. http://www.foxnews.com/story/0,2933,206713,00.html.

Javedanfar, Meir. "Iran's Big Crisis: The Price of Chicken." Bloomberg, August 7, 2012. http://www.bloomberg.com/news/2012-08-07/iran-s-big-crisis-the-price-of-chicken.html.

Johnson, Robert. "Iran Threatens To Torpedo US Carriers In The Persian Gulf.” Business Insider, January 18, 2012. http://articles.businessinsider.com/2012-01-18/news/30638111_1_supreme-leader-tehran-plans-iran-claims.

Katzman, Kenneth. Iran: U.S. Concerns and Policy Responses. Washington, D.C.: Congressional Research Service, March 23, 2012. http://fpc.state.gov/documents/organization/187401.pdf.

- Iran: U.S. Concerns and Policy Responses. Washington, D.C.: Congressional Research Service, October 4, 2006. http://fpc.state.gov/documents/organization/73926.pdf.

- Iran's Activities and Influence in Iraq. Washington, D.C.: Congressional Research Service, June 25, 2008. http://fpc.state.gov/documents/organization/108066.pdf.

Kaye, Dalia Dassa, Alireza Nader, and Parisa Roshan. Israel and Iran: A Dangerous Rivalry. Santa Monica: RAND Corporation, 2011.

Kerr, Paul. "IAEA Raises New Questions on Iran Program.” Arms Control Today, June 2006, June 2006 edition. http://www.armscontrol.org/act/2006_06/IAEAIranQuestions.

. "IAEA to Visit Two 'Secret' Nuclear Sites in Iran." Arms Control Today, January 2003. http://www.iranwatch.org/privateviews/ACT/perspex-act-secretnucsites-0103.htm.

"Khamenei Aide: Iran Will Increase Enrichment If World Pressure Persists.” Haaretz, July 21, 2012. http://www.haaretz.com/news/middle-east/khamenei-aide-iran-will-increase-enrichment-if-world-pressurepersists-1.452573.

Krause, Joachim, and Charles Mallory. The Strategic Implications of the Iranian Nuclear Program. Berlin, Germany: Aspen European Strategy Group, 2010.

Kristof, Nicholas. “An Interview with Mahmoud Ahmadinejad.” New York Times, September 21, 2011. http://kristof.blogs.nytimes.com/2011/09/21/an-interview-with-mahmoud-ahmadinejad/. 
LaFranchi, Howard. "Libya Fallout: Why Iran, North Korea Now Less Likely to Drop Nuclear Ambitions." The Christian Science Monitor, April 1, 2011. http://www.csmonitor.com/USA/ForeignPolicy/2011/0401/Libya-fallout-Why-Iran-North-Korea-now-less-likely-to-drop-nuclear-ambitions.

Landau, Emily. Decade of Diplomacy: Negotiations with Iran and North Korea and the Future of Nuclear Nonproliferation. Memorandum 115. Tel Aviv: The Institute for National Security Studies, Tel Aviv University, 2012.

- Iran After the Lebanon War: Same Nuclear Ambitions, Different Regional Context. Proliferation Analysis. Washington, D.C.: Carnegie Endowment for International Peace, August 14, 2006. http://carnegieendowment.org/2006/08/24/iran-after-lebanon-war-same-nuclear-ambitions-differentregional-context/ew0.

List of Revelations on Iran's Nuclear \& WMD Activities by the Iranian Opposition Since 2002. Nuclear Control Institute, 2006. http://www.nci.org/06nci/01-31/Revelations.htm.

Londoño, Ernesto. "Iran Intensifies Efforts to Influence Policy in Afghanistan.” Washington Post, January 4, 2012. $\mathrm{http}: / / \mathrm{www}$.washingtonpost.com/world/asia_pacific/iran-strives-to-play-spoiler-inafghanistan/2012/01/01/gIQAZ6gCbP_story.html.

Moradi, Shirin. "IRGC Backs Down from Threats to Close Strait of Hormuz." Inside Iran, July 24, 2012. http://www.insideiran.org/media-analysis/irgc-backs-down-from-threats-to-close-strait-of-hormuz/.

Mousavian, Seyed Hossein. The Iranian Nuclear Crisis: A Memoir. Washington, D.C.: Carnegie Endowment for International Peace, 2012.

"MP: Larijani Provoked Mousavi." Tehran Bureau, August 10, 2009.

Murphy, Brian. "Syria Captive Rift: Iran Defiant, Hezbollah Silent.” Associated Press, August 9, 2012. http://www.boston.com/news/world/middle-east/2012/08/09/syria-captive-rift-iran-defiant-hezbollahsilent/otN6FS1y1bRuic9UOwDpSO/story.html.

Nabili, Teymoor. "Mousavi Revives Reformist Vote." Aljazeera, June 13, 2009. http://www.aljazeera.com/focus/2009/06/2009612102154262910.html.

Nichols, Michelle. "Syria Conflict: Iran Supplies Arms To Assad Regime, U.N. Says." Huffington Post, August 22, 2012. http://www.huffingtonpost.com/2012/08/22/syria-conflict-iran-arms_n_1821816.html.

Nuclear Sites: Kalaye Electric Company. Washington, D.C.: Institute for Science and International Security, n.d. http://www.isisnucleariran.org/sites/detail/kalaye/.

Parker, John. Russia and the Iranian Nuclear Program: Replay or Breakthrough? Strategic Perspectives. Washington, D.C.: National Defense University, March 2012.

Parsi, Trita. A Single Role of the Dice. New Haven: Yale University Press, 2012.

Pellaud, Bruno. Testing Alternative Approaches. The Strategic Implications of the Iranian Nuclear Program. Berlin, Germany: Aspen European Strategy Group, 2010.

Perkovich, George. "Iran's Lebanon Card." Yale Global Online (August 24, 2006). http://www.carnegieendowment.org/2006/08/24/iran-s-lebanon-card/bm21.

Pfeffer, Anshel. “As Western Diplomacy Dithers, Iran's Foreign Policy Chief Chases Lebanese Support.” Haaretz, August 5, 2012. http://www.haaretz.com/blogs/the-axis/as-western-diplomacy-dithers-iran-s-foreignpolicy-chief-chases-lebanese-support.premium-1.456148.

Porter, Gareth. NIAC Memo:The Suspension Precondition: Lessons from Past EU-Iran Negotiation. Washington, D.C.: National Iranian America Council, July 13, 2006. http://www.niacouncil.org/site/News2?page=NewsArticle\&id=5890. “NIE Reveals Qom Facility Followed 2007 Bush Threats.” Inter Press Service News, October 23, 2009. http://www.ipsnews.net/2009/10/politics-nie-reveals-qom-facility-followed-2007-bush-threats/. "Understanding Iran's Diplomatic Strategy." Aljazeera, April 27, 2012. http://www.aljazeera.com/indepth/opinion/2012/04/2012422833676280.html.

Posch, Walter. "Iran and the European Union." In The Iran Primer. Washington, D.C.: United States Institute of Peace, 2010. http://iranprimer.usip.org/resource/iran-and-european-union.

Principles for Negotiating with Iran. Washington, D.C.: Bipartisan Policy Center, April 2012. http://bipartisanpolicy.org/sites/default/files/BPC\%20Iran\%20Paper\%20Negotiating\%20Principles_49.pdf.

Ravid, Barak. "Barak: New U.S. Intelligence Report Raises Urgency over Iran's Nuclear Program.” Haaretz, August 9, 2012. 
Recognizing Iran as a Strategic Threat: An Intelligence Challenge for the United Stated. Washington, D.C.: U.S. House of Representatives, Permanent Select Committee on Intelligence, August 23, 2006. http://www.fas.org/irp/congress/2006_rpt/hpsci082306.pdf.

"Report: Navy Commander Says Iran Has No Immediate Plan for Building Naval Reactors." Washington Post, August 9, 2012. http://www.washingtonpost.com/world/middle_east/report-navy-commander-says-iranhas-no-immediate-plan-for-building-naval-reactors/2012/08/09/b7f76aa4-e24e-11e1-89f776e23a982d06_story.html.

Response to the Iranian Announcement on Its Nuclear Facility in Esfahan. London, UK: U.K. Foreign and Commonwealth Office, March 31, 2004. http://www.iranwatch.org/government/UK/uk-fco-esfahanreax033104.htm.

Rozen, Laura. "Iran Complains over Preparations for Moscow Nuclear Talks." Al-Monitor, June 11, 2012. http://backchannel.al-monitor.com/index.php/2012/06/638/iran-complaints-escalate-ahead-of-moscownuclear-talks/.

"Key Advisor to Supreme Leader May Seek Iran Presidency." Al-Monitor, August 5, 2012. http://backchannel.al-monitor.com/index.php/2012/08/1551/key-advisor-to-supreme-leader-may-seek-iranpresidency/\#more-1551.

Rubin, Alissa. "Nations Move Closer to Unity on Iran Strategy." Los Angeles Times, May 31, 2006.

"Russia Urges Iran to Cooperate with UN on Nuclear Program." Reuters, June 15, 2011. http://www.haaretz.com/news/world/russia-urges-iran-to-cooperate-with-un-on-nuclear-program-1.367908.

Saad-Ghorayeb, Amal. “Hezbollah's Iran Money Trail: It’s Complicated.” Al Akhbar, July 31, 2012. http://english.al-akhbar.com/node/10553/.

Sahimi, Muhammad. "Q\&A: Former Iran Nuclear Negotiator: Bush Negotiation Bid Was Rebuffed." Tehran Bureau, May 12, 2012. http://www.pbs.org/wgbh/pages/frontline/tehranbureau/2012/05/qa-former-irannuclear-negotiator-bush-negotiation-bid-was-rebuffed.html.

Sanger, David. "North Korea Says It Now Possesses Nuclear Arsenal." New York Times, April 25, 2003.

Saunders, Emily. Case Study: Iran, Islam, the NPT, and the Bomb. Livermore, California: Lawrence Livermore National Laboratory, June 2010.

Sciolino, Elaine, and Michael Slackman. "Before Nuclear Regulators' Meeting, Iran Allows Inspectors Access to One Site.” New York Times, January 30, 2006.

http://www.nytimes.com/2006/01/30/international/middleeast/30nuke.html?ex=1139202000\&en=b4bc4c9a 1 bee5b07\&ei $=5099 \&$ partner $=$ TOPIXNEWS.

Segall, Michael. "Iran Takes Off the Gloves." Jerusalem Issue Briefs 12, no. 5 (March 28, 2012). http://jcpa.org/article/iran-takes-off-the-gloves/.

"Senior Iranian Cleric Slams Media Restrictions." Mehr News Agency, August 9, 2012. http://www.payvand.com/news/12/aug/1071.html.

Shanker, Thom, Eric Schmitt, and Alissa J. Rubin. "U.S. Sees Iran in Bids to Stir Unrest in Afghanistan.” New York Times, April 4, 2012. http://www.nytimes.com/2012/04/05/world/asia/irans-efforts-to-stir-afghan-violenceprovoke-concern.html?pagewanted=all\&_r $=0$.

Shuster, Michael. "Iran’s Nuclear Fatwa: A Policy Or A Ploy?” NPR, June 14, 2012. http://www.npr.org/2012/06/14/154915222/irans-nuclear-fatwa-a-policy-or-a-ploy.

Statement by the Legal Adviser to the IAEA Board of Governors. International Atomic Energy Agency, March 2009. http://www.armscontrolwonk.com/file_download/162/Legal_Adviser_Iran.pdf.

Tait, Robert. "Ayatollah Ali Khamenei Criticises Attack on British Embassy.” The Telegraph, August 8, 2012. http://www.telegraph.co.uk/news/worldnews/middleeast/iran/9461842/Ayatollah-Ali-Khamenei-criticisesattack-on-British-embassy.html.

"Kidnappings Came Day Before UN Resolution.” The Guardian, March 26, 2007. $\mathrm{http} / / / \mathrm{www}$. guardian.co.uk/world/2007/mar/26/iran.roberttait.

Tavernise, Sabrina. "Russia, Turkey and Iran Meet, Posing Test for U.S." The New York Times, June 8, 2010, sec. World. http://www.nytimes.com/2010/06/09/world/09iran.html.

Timmerman, Kenneth. "Iran Ordered Attack on Israel, Official Says.” NewsMax, July 24, 2006. http://archive.newsmax.com/archives/articles/2006/7/23/171949.shtml.

“Top Commander: Hormuz Strait Closure Plan Ready for Action.” Fars News Agency, July 15, 2012. http://english.farsnews.com/newstext.php?nn=9104250042.

"UN Security Council Dictating to IAEA on Iran Case, Illegal." PressTV, July 4, 2012. http://www.presstv.ir/detail/2012/07/04/249277/unsc-drilling-of-iaea-on-iran-is-illegal/. 
Vick, Karl. "Blame Saddam: Another Way of Seeing Iran's Nuclear Program.” Time Magazine, April 19, 2012. http://world.time.com/2012/04/19/blame-saddam-another-way-of-seeing-irans-nuclear-program/.

Walberg, Eric. "From OIC to NAM: Iran's Peace Offensive.” Dissident Voice, August 22, 2012. http://dissidentvoice.org/2012/08/from-oic-to-nam-irans-peace-offensive/.

Weymouth, Lally. “An Exclusive Interview with Mahmoud Ahmadinejad.” Slate, September 13, 2011. http://www.slate.com/articles/news_and_politics/foreigners/2011/09/an_exclusive_interview_with_mahmo ud_ahmadinejad.single.html.

Yaphe, Judith, and Charles Lutes. Reassessing the Implications of a Nuclear-Armed Iran. McNair Paper 69. Washington, D.C.: National Defense University Press, 2005. http://www.ndu.edu/inss/docuploaded/McNair69.pdf. 